\title{
Thrasymachus of Chalcedon on the Platonic stage
}

Dorota Zygmuntowicz

The conviction that Plato manipulated Thrasymachus' views is today accepted by the scholarly opinion. Given the absence of testimonies regarding the political and moral views held by the historical Thrasymachus, the degree of this manipulation can be gauged only by assessing the degree of incoherence and ambiguity in the views of the Platonic Thrasymachus. This perspective, of necessity a self-referential one, is overcome by the hypothesis presented in the following article, namely, that Plato manipulates not as much the views of the historical Thrasymachus as the extremely concise and ambiguous thesis (that justice is "the advantage of the stronger") which he has ascribed to him; and that the goal of this manipulation is to mock Thrasymachus' style and rhetorical posture - both confirmed by testimonies outside the Platonic text - as ill suited to the philosophical reflection on the content of this thesis.

\section{Introduction}

If it had not been for Plato, Thrasymachus of Chalcedon would be familiar to merely a group of philologists and experts on ancient rhetoric working on meagre source material: the few extant fragments of his writings and later writers' references to his exceptional style and input into the development of rhetoric. Those scholars would have had no basis whatsoever to ascribe to him the views which, owing to Plato, arouse such wide interest, especially among modern-day philosophers and historians of political thought. ${ }^{1}$ These views are summed up by the famous definition of justice: "the just is nothing other than the advantage of the stronger" (Rep. 338c1-2), ${ }^{2}$ where the function of the differentia specifica is fulfilled by the clarification

\footnotetext{
${ }^{1}$ Even seventy years ago George B. Kerferd was justified in saying that fifty years after Eduard Schwarz had complained against the cursory treatment, instead of the due justice that scholars gave Trasymachus of Chalcedon, his complaint was still fully valid (Kerferd 1947, 19). Today, Schwarz's complaint is no longer applicable: over the last five decades, so many articles and book chapters concerning the doctrine of Thrasymachus as expounded in Republic 1, and the authenticity and coherence of Plato's image of Thrasymachus, have been written that their list would swell this footnote to the length of several pages (over ten years ago, a similar observation was made by Nederman 2007, 26 n. 2).
}

${ }^{2}$ Translations of the Republic are from Bloom 1968. 
posed at the outset of the debate that, regardless of the political system, "the stronger" is the one currently holding power (338d7-339a4; hereinafter, "Thrasymachus' thesis" will be abbreviated to TT).

Of course, argument derived from the silence of the sources is not sufficient to deny the doctrine of the Platonic Thrasymachus' historical credibility. On the other hand, it is obvious that Plato was happy to place historical figures into the dramatic scenery he had created; a scenery subordinate to his own goals and philosophical methods. This fact was curtly expressed by Athenaeus, who said that Plato had slandered Thrasymachus as he had so many others, and mentioned his other victims: Hippias, Gorgias and Parmenides, all of them men of no small standing in the history of philosophy (Deipn. $11505 \mathrm{c}-\mathrm{d})$. He also reported that

Gorgias himself, when he read the dialogue to which Plato has given his name, said to his friends, "how well Plato knows how to write iambics!" [...] But others say that Gorgias, having read the dialogue of Plato, said to the bystanders that he had never said any of the things there attributed to him, and had never heard any such things said by Plato. And they say that Phaedo also said the same when he read the treatise on the Soul [...]. $(11505 \mathrm{e})^{3}$

Considering the image of Thrasymachus in the extant testimonies, which only note his achievements in the area of rhetoric, as well as the likelihood of Plato having manipulated the figure of Thrasymachus, ${ }^{4}$ the following question is indeed justified: did the greatness and originality of the historical Thrasymachus lie in what he said, or rather in how he said it? Plato's image of the rhetorician reveals the form and the content of a certain teaching; yet history has saved only the form. Contemporary scholars, on the other hand, are interested in the moral and political content: some of them view it as ambiguous and incoherent, others as more or less unambiguous and thus possible to interpret (from a certain perspective) as coherent. Yet perhaps Plato too perceived the rhetorical style of Thrasymachus as so striking and intriguing that the thesis ascribed to him was no more than a tool for a polemical - and comical - exaggeration of a certain rhetorical manner; a tool that served Plato's overall goal of looking for his own, appropriate form to express his reflection on the content - expressed by many members of his

\footnotetext{
${ }^{3}$ Trans. C.D. Yonge. Also Dionysius of Halicarnassus accuses Plato of mocking his predecessors, adding Protagoras, Prodicus, Polus and Theodorus to the above list of his victims (including Thrasymachus) and looking to Plato's philotimia as the reason (Epistola a Pompeo Gemino, 756). As pointed out by Kutash 2007, 10, Plato's references to other thinkers were not aimed at reporting their views according to the modern standards of scholarly writing; Plato treated them as a background to the reworking of the key concepts in accordance with his own values.

${ }^{4}$ This view is generally accepted since the debate between Kerferd 1947, 1964 and Hourani 1962 (with later input from, among others, Sparshoot 1966, Harrison 1967, Maguire 1971; see also Lycos 1987, 41; Nederman 2007, 29-32, 37).
} 
intellectual environment - which he condensed in the terse TT. ${ }^{5}$ This supposition seems all the more justified considering that the Laws $(714 \mathrm{~b}-\mathrm{d})$ ascribes TT to a collective spokesman and presents it in a clear and unambiguous manner, thus showing that the content which Plato's Thrasymachus seems unable to express clearly and coherently is, in fact, capable of being thus expressed. ${ }^{6}$

This question points the direction for the analyses offered herein. Differently than the majority of interpreters, who focus on what the Platonic Thrasymachus had said, I concentrate on the how of it, since I am convinced that, firstly, the manner of presenting the character Thrasymachus, and the thesis ascribed to him, points to what exactly intrigued Plato about the rhetorician - his style or the content of his views; and secondly, that the manner in which Plato made use of Thrasymachus offers an indirect answer to the content of TT. ${ }^{7}$ To substantiate this approach, I wish to show that, firstly, the absence of testimonies regarding the views of the historical Thrasymachus that would allow us to ascribe TT to him is reflected in the distinctive manner these views are presented in the Republic itself; secondly, that the problems contemporary recipients have with interpreting TT are, remarkably, parallel to the problems of the dialogue's interlocutors. In short, by comparing the rhetorical style of the historical Thrasymachus as confirmed in the sources and testimonies with the manner the rhetorician had been portrayed by Plato, I aim to weaken the claim posed by Cary J. Nederman, as accepted by many scholars, that "Plato's characterization of 'Thrasymachus' bears only passing resemblance to its historical exemplar". ${ }^{8}$

\footnotetext{
${ }^{5}$ Had Plato made Antiphon, Thucydides, Critias or Callicles - who remains unidentified but whose views are known from Gorgias - express the TT, its interpretations might have been offered more vigorously, driven by the richer and more coherent comparative material than is the case with the writings of Thrasymachus. Extant source testimonies allow for the following identities: Thrasymachus stands for Thucydides (as e.g. Oswyn Murray in Boardman, Griffin, Murray 1986, 196; cited after Mitchell 2003, 5, who approves of this view), or Plato's two figures, Thrasymachus and Callicles, are Antiphon (as e.g. Barney 2017, who suggests that the historical model for Plato's three faces of immoralism, i.e. Callicles, Thrasymachus and the latter's defenders Glaucon and Adeimantus, was the sophist Antiphon); cf. also Thesleff 1982, 257-8: Thrasymachus stands (partly) for Thrasybulus. In any case, Plato chose Thrasymachus for some reason. This article is concerned with the question of what that reason may have been.

${ }^{6}$ This "intriguing contrast" is noted by Nederman 2007, 36, although with a different explication.

${ }^{7}$ The question of how Thrasymachus speaks about justice is stressed by Anderson 2016. However, his interpretation is focused on the methods of sophistic argumentation Thrasymachus accepts for discussing the nature of justice and politics, not on the way Plato is drawing the character Thrasymachus.

${ }^{8}$ Nederman 2007, 26-7. See also White 1995, 307-8, for a similar point: Plato's Thrasymachus is the devastating caricature of the historical Thrasymachus; Maguire 1971, 143.
} 
The question as to the how cannot be separated from the question as to the what, as the former pertains to the latter and is, therefore, secondary to it. In the case of Thrasymachus and his thesis, the question concerning the secondary matters has its anchorage in the sources Plato's Republic and a few references to Thrasymachus in the Phaedrus; whereas the question concerning the primary matters, i.e. the subject, is devoid of such a reference due to the scarcity of the source material regarding Thrasymachus and his views. And yet, the fundamental fact concerning the "what" is the historical realness of Thrasymachus. ${ }^{9}$ This does not mean that the first readers of the Republic fell victim to a similar exegetic confusion. It is probable that, being familiar with the methods for the artistic manipulation of the image of a well-known figure in theatre, they were able to recognise the model for Plato's construction of Thrasymachus regardless of the degree to which he had been deformed by Plato and of the possibility that Plato ascribed to him words the rhetorician had never uttered. ${ }^{10}$ The innovative reworking of ancient and well-known Homeric themes, which was typical of tragedy, and the caricaturing deformation of the recognisable features of actual historical or contemporary figures, which was typical of comedy, as well as the manner of presenting the mocking image of one's opponents, characteristic of the ancient polemical style - all those were procedures owing to which (in view of the first recipients of TT) the tragicomic deformation of the image of Thrasymachus possibly perpetrated by Plato did not cancel the features that allowed them to identify the model, but only imparted a calculated tinge for the purpose of the polemic. Regardless of whether this tinge fulfilled a purely artistic, rhetorical or even a paideutical/philosophical function, it is hardly intelligible to us. Yet it is precisely the scope and the manner of the philosopher-artist's interference with the model that may indicate the purpose of the resulting image and may intensify its meaning.

Yet, even though the figure of the historical Thrasymachus appears to us shattered into a dozen small fragments and testimonies strewn over the period of thirteen centuries (ending with the Bibliotheca by Photios and the Suda lexicon dating from the second half of the $9^{\text {th }}$ century), these images have retained a message that is clear and coherent enough for us to refer

\footnotetext{
${ }^{9}$ The extant fragments of his writings are insufficient to ascribe a definite philosophical or political stance to the historical Thrasymachus, as shown by Betti 2011, 33-44 (therein an outline of positions and debates on the credibility of Plato's Thrasymachus).

${ }^{10}$ Writers of the classical period did not see as unusual the method of having some other person express their own views; this was done by historians and by orators, who composed speeches on commission (see especially Livingstone 1998, 273). On the other hand, cf. the results of Ledger's $(1989,104,117)$ stylometric research on the speech in the Phaedrus $(230 \mathrm{e}-234 \mathrm{c})$, which is ascribed by Plato to Lysias; following the results of this research, many scholars treat it as an authentic speech by Lysias (Nails 2002, 193).
} 
them to relevant passages from the Republic and thus not only restore the slightly faded colour to those passages, but also to present those shards of testimonies as a part of the whole to which Plato alludes. Let us, therefore, have a look at the contents of those fragments themselves; let us bear their monotonous style and damaged contents patiently, in the hope that they will to some extent regain their lost form and colour on the grand stage of the Republic (the fragments to which I shall refer further on, in discussing the Republic, are indicated with letters in bold script, in square brackets)..$^{11}$

\section{To whom did Plato ascribe TT?}

\section{The non-Platonic testimonies}

[A:] In the earliest testimony, dating from the year 427, i.e. more or less from the period of Plato's birth, the young Thrasymachus is already a topic of comedic ridicule. He turned the attention of the very young Aristophanes: in his first comedy Daitales (Banqueters, fr. $205.8=$ DK fr. A4), Thrasymachus' name is used by a staunchly traditionalist father in order to mock and chastise his rebellious son, who is all too ready to yield to the influence of the rhetoricians' newfangled adages. ${ }^{12}$ The fact that Thrasymachus was here mentioned in the same context as

\footnotetext{
${ }^{11}$ The most recent collection of fragments and testimonies concerning Thrasymachus is found in Laks and Most 2016, 475-513 (hereafter LM). It extends the list given by Diels and Kranz to include the views ascribed by Plato to Thrasymachus and separates the contents of those testimonies which in DK's collection are given, following the source texts, as a single continuous report, into thematic groups. Fragments cited following both those collections are herein indicated with (DK/LM); their translation is given following LM. Fragments without this indication are not included in either collection.

12 The son whose father calls him, mockingly, "Thrasymachus", is named Katapygon. In Greek, this word means not only a passive homosexual, but also, more broadly, a man shameless in political and moral life. If this play was shown at the Lenaeae in 427 (see Bromberg 2018, 37, with a bibliographical note), then by the age of 28 Thrasymachus was already a well-known rhetorician - assuming that he was born ca. 455. This date is suggested by Dion. Hal. Dem.3 (= DK fr. B1/LM fr. D16; see below [D1]), as long as we accept that the speech - which includes the theme of a young man apologising for speaking up in public first - was presented by Thrasymachus in 407, i.e. when he was less than 50 years of age, in his own name (see n. 18 below). On this topic, see Nails 2002, 288-90, polemically to White 1995, 324-5, who, perceiving the Thrasymachus of the comedy to be a different person than the one in the Republic and in DK fr. B1/LM fr. D16, suggests that in Athens in the second half of the $5^{\text {th }}$ century there were two famous rhetoricians of that name (a similar view in Storey 1988, 212-8, who suggests that this is the given name of Katapygon; for a criticism of his argument, see Bromberg 2018, 47 n. 43). This is not only improbable, as pointed out by Nails, but also not confirmed by any extant testimonies: when they refer to the rhetorician Thrasymachus, they clearly refer to just one person, i.e. Thrasymachus of Chalcedon. Five other men from the Classical period bearing that name, probably neither of them a rhetorician, are noted in the sources: 1) a casualty of war in 423 ; 2) a character in Theopompus' Stratiotides; 3) a dead uncle of the plaintiffs in Isaeus 4 (see White 1995, 324 for these three references); 4) Thrasymachus of Corinth $\left(4^{\text {th }} \mathrm{c}\right.$.), possibly the teacher of Stilpo of the Megarian school (DL II 113);
} 
the 23-year-old Alcibiades is significant: born at Chalcedon in Bithynia (Suda, $T h=\mathrm{DK}$ fr. A1/LM fr. P1) and attached to his city until the end of his life, since he was buried there (Athen. Deipn. $10454 \mathrm{~F}=\mathrm{DK}$ fr. A8/LM fr. P6), in Athens he had the status of a foreigner; the presentation of his person onstage as an equal to the wealthy, handsome, and articulate Athenian aristocrat Alcibiades must then have been due to Thrasymachus' remarkably vivid personality and, despite his young age, his already significant achievements in the area of rhetoric or oratory. In fact, his rhetorical talent and exceptional character are highlighted in the entire set of the extant testimonies.

[B:] Thus Aristotle, taking into consideration his full oeuvre, counts him among the first rhetoricians and, charting the development of the rhetorical art, places him directly after Teisias, who in turn comes "after the very first ones" (Arist. SE 34 183b29-33 = DK fr. A2/LM fr. D7). [B1:] The titles and topics of his works as noted in the testimonies include: Sumbouleutikoi (Deliberative Speeches), Paignia (Amusements, probably of the mythological type), ${ }^{13}$ Aphormai retorikai (Rhetorical Starting Points), Techne retorike (A Technical Manual of Rhetoric) - possibly known under the older, more expressive title Megale techne (Large Technical Manual) that is extant in the scholia to the Birds by Aristophanes $(\operatorname{ad} A v .880=\mathrm{DK}$ fr. B3/LM fr. D3) - (Suda, Th = DK fr. A1/LM fr. D2), Huperballontes (Overpowering Ones, scil. Arguments; Plut. Quaest. conv. 1.2.3 616D = DK fr B7/LM fr. D5), ${ }^{14}$ and [B2:] Eleoi (Expressions of Pity) - the only work by Thrasymachus mentioned by Aristotle and by Aristotle only - which pertains to the manner of delivering speeches (Rhet. 3.1. 1404a13-15 $=$ DK fr. B5/LM D6, D14; in this context, Thrasymachus is mentioned on one occasion by Quintilian, Inst. or. 3.3.4 = LM fr. D15).

[C:] Speeches belonging to the above thematic sections were written on commission or for didactic purposes. The first group includes the speech Huper Larisaion (For the Larissians), from which one line rewritten from Euripides (fr. 719) is cited by Clement of Alexandria as a case of plagiarism: "Shall we, who are Greeks, be slaves to Archelaus, who is a barbarian?" (Strom. 6.16.6 = DK fr. B2/LM fr. D18). ${ }^{15}$ [C1:] In turn, his activity as a pedagogue is confirmed by Cicero, who mentions Thrasymachus together with Gorgias and Isocrates as those who did

5) Thrasymachus who overturned democracy at Cyme (Arist. Pol. 1305a; cf. White 1995, 319, 326-7, who identifies him with Thrasymachus the author of the speech preserved as DK fr. B1).

${ }^{13}$ Dobson 1919, 51.

${ }^{14}$ Dobson 1919, 50 is probably wrong in saying that this work is mentioned by Aristotle.

${ }^{15}$ White 1995, 319 argues that "the point of Thrasymachus' indignant question was probably to urge resistance to Archelaus' aggresion and support for Thessalian autonomy." 
not much engage in the matters of state as active politician but taught political wisdom (sapientia) instead (De orat. III 59); ${ }^{16}$ similarly, following Metrodorus, Cicero's nearcontemporary Philodemus (Rhet. $2.49=\mathrm{DK}$ fr. B7a/LM fr. R10). Cicero is also the only author who credits Thrasymachus with wider interests than strictly rhetorical ones, asserting that, similarly to many outstanding ancient orators, he spoke and wrote about many essential topics, including nature (De orat. III $128=$ DK fr. A9/LM fr. D4). Nothing is known about the contents of those teachings, or even the titles of the relevant works. [C2:] Certainly the epigram on his grave: "Profession: wisdom" (he de techne sophie; Athen. Deipn. 10 454F = DK fr. A8/LM fr. P6) goes beyond the possibly slanted image of Thrasymachus as a master of rhetorical techniques. Again, however, the later generations are silent on the contents of this wisdom, almost as if, impressed with its rhetorical form, they forgot to refer to it.

[D:] Dionysius of Halicarnassus, later than Cicero by ca. 40 years, has access to many works by Thrasymachus and studies them diligently; he is, however, interested primarily in rhetoric and thus considers Thrasymachus in this perspective: stressing that all his achievements are contained in (pas de estin en) "technical manuals and oratorical displays" (Isaeus $20=\mathrm{DK}$ fr. A13/LM fr. D1). As a result of this approach, he discusses these achievements, similarly to those of, e.g., Plato or Thucydides, solely in terms of rhetoric. ${ }^{17}$ [D1:] Viewing Thrasymachus from this limited perspective, Dionysius cites the longest extant fragment of "one of his public speeches" (henos ton demegorikon logon), known as "A proem for a Speech in a Political Crisis" (Dion. Hal. Dem. 3 = DK fr. B1/LM fr. D16). Given most probably during the Decelaean War (413-404) or the revolt from Athens in Chalcedon $(412-407)^{18}$ - in the possible dramatic time of the Republic - and addressed explicitly to the Athenians, ${ }^{19}$ this speech expresses a yearning for the "olden days," when the elders ruled the polis correctly (orthos), thus not forcing the young men to speak out publicly, and criticism of the current times, when the subjects must suffer calamities caused by neither gods nor fate, but by the "men in charge" (ton epimelethenton, cf. Rep. 343b-c). [D2:] Considering this state of affairs - the past times of mutual accord (homonoia) changing into the current times of mutual enmity (echthra) -

\footnotetext{
${ }^{16}$ The same triad of great orators is mentioned by Cicero again in Orat. $13.40=$ DK fr. A12/LM fr. R1.

17 A similarly one-sided perspective is seen in the Suda, noting that Vestinus Julius composed "an Anthology of texts from Thucydides, [...] Thrasymachus the orator, and the other orators" (Suda O. 835 $=$ DK fr. A14/LM fr. R5).

${ }^{18}$ The latter context is accepted by White $1995,316,325$, who pinpoints Thrasymachus' speech in the summer of 407.
}

${ }^{19}$ On Sylburg's supplement $O$ Athenaioi for the abbreviation in the manuscripts, see White 1995, 312. 
Thrasymachus calls to action, even if it were only a verbal one: "[...] it is necessary to speak. For someone would have to be unfeeling or entirely uncomplaining, to still be willing to submit himself to men who wish to do wrong (examartanein) and to bear the responsibility himself for other men's conspiracy and wickedness." [D3:] No-one should hesitate to speak out if he knows what to say, if he suffers because of the current situation and thinks he has "a means such that he can put a definite end to this sort of situation." Following this appeal, the rhetorician presents the plan for his presentation of the means to resolve the political crisis. [D4:] First he will present (apodeixei) the suffering of those who argue ("whether orators or other people"), which must be the same as the suffering of those who vie with each other "for victory without judgment:" thinking they are making contradicting points, they do not see that they are saying the same things. Then he appeals to his listeners to "consider from the beginning (skepsasthe ex arches) what both sides are looking for," and in one sentence summarises that object: arguing about the patrios politeia, they all treat it as a thing of great value. [D5:] It is thus necessary, exhorts Thrasymachus thereinafter, to listen to what the elders have to say on the issues that are beyond the recognition of the young and to "find out from those who know $[\ldots]$ " On this Dionysius ends his quotation, as it was enough for him to present the style (lexis) of Thrasymachus. ${ }^{20}$ The tenor of his remedy to a political crisis goes beyond Dionysius' interest. Much as this remedy may be evoked - in a more or less perfidious manner - in the Republic, and therefore reveal, by contrast, the intentions of Plato's Thrasymachus, in fact, the fragment arouses scepticism as to the actual views of the Chalcedonian. It is cited solely with the intention of comparing the styles of Demosthenes and Thrasymachus, who was also famous for writing speeches on commission, and does not constitute a strong basis for ascribing the views presented therein to the rhetorician himself. ${ }^{21}$ But there is a basis for ascribing to him not only

\footnotetext{
${ }^{20}$ For the references to the modern analyses of his style, see White 1995, $308 \mathrm{n} .7$.

${ }^{21}$ It is not certain whether Thrasymachus composed this speech on commission from some Athenian or presented it to the Athenian Assembly in his own name. (In the rendition of damaged verses 8-9, Blass supports the traditionally accepted first option, whereas Diels the second, followed by White 1995, who sees Thrasymachus as an envoy from Chalcedon. Despite White, Yunis 1997, 58-66; equally critically, Betti 2011, 43; White's argumentation is supported by Nails 2002, 289.) In addition, it is not clear which side of the conflict Thrasymachus considered as endowed with the quality of patrios politeia, since, as Betti 2011 demonstrated (referring mainly to Munn 2000), the aristocrats and the democrats, the moderate oligarchs and the progressive liberals all pleaded patrios politeia, wishing to legitimise their own claim to rightness and power by referring to tradition (Betti 2011, 34-5, 37-40; cf. White 1995, 313-4). It must be noted that the plea for the "ancestral constitution" by all the sides of the conflict and thus motivated not by a true concern for the polis, but by each political fraction's desire for victory over the other - was highlighted by Thrasymachus himself in [D4]. This point is stressed by Guthrie1971, 296, who quotes Havelock's view that the fragment is an expression of political objectivism and presents "a rationale of political behaviour and method, if not a theory of politics", and adds that Thrasymachus' observation that "party struggle is based on the thirst for power rather than on
} 
the point which, according to Dionysius, is illustrated by this prooimion, i.e. the combination of the lofty style with the plain style, but also a characteristic rhetorical strategy revealed therein, relying on assuring his listeners that he is in possession of a special concept, in this case: a remedy to a political crisis, in the form of a speech revealing the state of affairs (see [D3]).

[E:] A testimony that Thrasymachus was concerned not only with the style of the speeches, writings or teachings, but also with the manner of their delivery, is given by Aristotle in the Rhetoric, citing the title of the relevant work by Thrasymachus - Eleoi, and by Quintillian (see [B2]). It was precisely the manner in which Thrasymachus gave the speeches, using special techniques of persuasion, that imparts a distinct feature to him which was noted by Plato's contemporaries. This is confirmed once again by Aristotle as he quotes Herodicus, considered identical with the gymnastics teacher mentioned in the Protagoras (316d), turning to Thrasymachus with the words: "You are always reckless (thrasy-) in battle (-makhos)" (Rhet. $2.231400 \mathrm{~b} 18-20=\mathrm{DK}$ fr. $\mathrm{A} 6 / \mathrm{LM}$ fr. P4). It is not known whether this indicated Thrasymachus' determination/valour in a gymnastic or an eristic contest. [E1:] Thrasymachus' contemporary, the orator Lysias, shows him as a member of an association (sunousia) embroiled in an internal conflict due to mutual charges of libel and intrigue (Lys. 8.14-16). [E2:] On the other hand, the proem to one of Thrasymachus' speeches as reported by Athenaeus indicates that the orator may have referred in his speeches to a variety of motifs connected with struggle and force. It tells of Timocreon of Rhodes, whom the king of Persia invited to a feast and who ate with gusto. Asked what he wanted to do after such an opening, he said that he wished to vanquish "more Persians than could be counted," and he proceeded to do so the following day, gaining victory over a large number of contenders and still retaining the power of his punch for other opponents (Deipn. $10416 \mathrm{~A}=$ DK fr. B4/LM fr. D19). [E3:] Aristotle praises Thrasymachus for the manner in which he used the metaphor of the Homeric heroes' fight in the context of Niceratus' weakness in a rhapsodic competition (Rhet. 3.11 1413a5-9= DK fr. A5/LM fr. D20). [E4:] Dionysius, in turn, points to the fact that Thrasymachus himself was famous for combative rhetoric (enagonios) and mentions two main features of his style: first, his precision (akribeia; Isaeus $20=$ DK fr. A13/ LM fr. D8), describing the rhetorician as "pure, subtle, excellent at inventing and expressing what he means in a compact and refined way" (Isaeus 20 = DK fr. A13/LM fr. R2); secondly, his combination of the austere style and 
the simple style, resulting in an orderliness which prose retained "until today" (Dem. $3=$ DK fr. B1/LM fr. D9). ${ }^{22}$ The first feature - the ability to condense thoughts and to express them tersely - is considered by Dionysius to be one of the greatest assets of Thrasymachus' style, and praised again elsewhere (Lys. $6=\mathrm{DK}$ fr. A3/LM fr. R3) ${ }^{23}$ the second one is considered by him praiseworthy in terms of intentions, but in terms of implementation, he values Demosthenes more than Thrasymachus (Dem. 3 = DK fr. B1/LM fr. R4). Thus, despite this small point of criticism, we obtain a picture of Thrasymachus as stately, sharp, and precise in his attacks - as a truly formidable opponent at the arena of a rhetorical contest.

[F:] Finally, an impassive face must be added to these assets of a combative orator, since Photios, probably following Aelius Aristides, mentions Thrasymachus as a sophist who never blushed (Bibl. cod. 248, 437b). This - interestingly, Photios' sole mention of Thrasymachus might seem an inconsequential feature of physiognomy, if it were not for the fact that Plato in the Republic shows Thrasymachus as blushing (Rep. 350d3). Regardless of whether this description of the historical Thrasymachus is understood as indicating a natural paleness or an assumed, dramatic immobility of his face, Plato's reference to his physiognomy is intended as comical. Thus we catch him on a small perversity. It is not known, however, whether this is limited to the features of character and appearance, or whether it extends to the content of his teachings.

\section{The Platonic Testimonies}

[G:] The move from the fragmentary image of the "historical Thrasymachus" to the full image of "Plato's Thrasymachus" is facilitated by the mediation of the Neoplatonist Hermias (first half of the $5^{\text {th }}$ c. AD). [G1:] Commenting on one of six passages from the Phaedrus that refer to Thrasymachus, he cites the historical Thrasymachus and thus provides us not only with a testimony to the "might" (sthenos) of Thrasymachus' delivery (In Phaedr. 267c, p. 251.18-22 $=\mathrm{DK}$ fr. B6/LM fr. D13a-b), which astounded Plato and his contemporaries, but also a passage

\footnotetext{
${ }^{22}$ According to Theophrastus, Thrasymachus had been the first to give a distinct form to prose; Dionysius himself has doubts as to whom this supremacy should be attributed (Dion. Hal. Dem. 3); Cicero mentions two protagonists: Thrasymachus and Gorgias (Orat. 13.40= DK fr. A12/LM fr. D10); the Byzantine Suda lexicon agrees with Theophrastus.

${ }^{23}$ And he is again uncertain as to who should be credited with the discovery of this style (cf. note 22); himself, he sees Lysias as that person (mistakenly assuming that Lysias had been older than Thrasymachus; Lys. $6=$ DK fr. A3/LM fr. P2) - contrary to Theophrastus, who again credits Thrasymachus with being the first. Thrasymachus' terse phrases are noted by Cicero as well (Orat. 13. $40=$ DK fr. A12/LM fr. R1).
} 
from his writings - one and only that may serve to explain why Plato credited him with sthenos through the argument of not the form, but of the content of Thrasymachus' teachings (In Phaedr. 267c, pp. 251.22-252.2 = DK fr. B8/LM fr. D17). Thus, in the Phaedrus 267c-d, Plato explains the exceptional sthenos of the Chalcedonian - at least against the background of the achievements of all other sophists of the age (see [A], [B]) - as springing from his ability (techne) to give "plaintive speeches," and calls him a "mighty man" (deinos haner) because "as he said" (hos ephe), puts in Plato, possibly quoting him - he can at the same time "make the crowd angry" and "beguile them with incantations when they have become angry;" he adds that the Chalcedonian is "the best (kratistos) at slandering and at quashing slanders" (cf. [E1]). In commenting on this passage, Hermias explains that the man in question was Thrasymachus, who taught how to move judges to compassion and pity (eleos). He probably has in mind Thrasymachus' work Eleoi mentioned by Aristotle ([B2], [E]). But Hermias is not certain why Plato ascribed the quality of sthenos to him; yet his doubt concerns not the validity of the attribution, but to the grounds for it. Hermias considers two options: either "the impetuosity of his discourse" (ten dunamin tou logou autou), or the contents of one of his texts. [G2:] Here the Neoplatonist - himself interested more in philosophy than in the technicalities of rhetoric provides us with the only fragment from Thrasymachus to concern justice:

[...] the gods do not notice human affairs: for otherwise they would not have failed to take notice of what is the greatest good for humans, justice. For we see that humans do not practice this.

Unfortunately, Hermias did not refer to TT. If TT - which, after all, prescribes justice - was formulated by the historical Thrasymachus, i.e. the author of the above opinion, it appears, in its context, as a bitter assessment of what the ersatz of justice is - the only kind available to mankind in the absence of the true, i.e. divine, justice. ${ }^{24} \mathrm{~A}$ similar bitterness is evident in the Prooimion reported by Dionysius ([D1]-[D2]), which contrasts the old homonoia to the current hostility.

[H:] There is no basis whatsoever to ascribe TT to the historical Thrasymachus. There is, however, reason to believe that all the references to Thrasymachus in the Phaedrus, written after the Republic, are purely historical, devoid of any elements of the literary creation of a protagonist as present in the Republic 1 . This is because there, Thrasymachus is not a person

\footnotetext{
${ }^{24}$ The view that the gods failed to give the human race justice contradicts the teachings of Plato's Protagoras, who, in the myth on the beginnings of political life (the art of politics), says that without the feelings of shame and justice, given to mankind by Zeus, people would have killed themselves to extinction (Prot. 322c). It is, however, consistent with the view stated by Critias: "There is no justice among the currently living" (DK B12).
} 
with whom Socrates converses, i.e. a character from the inside of the dialogue, whose makeup might be worth a slight accentuation for the reasons of drama or polemics; he is a representative of the art of rhetoric, which is an external and prior to the dialogue reality being discussed by Socrates and Phaedrus. [H1:] Plato's perception of Thrasymachus as an outstanding rhetorician is also suggested by the passage $261 \mathrm{c} 1-3$, where he is mentioned as the author of writings on the art of rhetoric, together with Gorgias (compared to Nestor) and Theodorus ([H2:] with whom Plato disguises him as Odysseus) (cf. [B], [C1]). [H3:] In the passage 266c2-8 Plato connects him with Lysias and ascribes to them (in keeping with their own view of themselves) wisdom based on the art of speech which - almost like kings who had received gifts - they pass on to others (cf. [C1]-[C2]). This, however, was not Socratic art, as pointed out by Plato, based on the dialectical knowledge of the nature of a given object (266c8). Without it, both Lysias and Thrasymachus remain in the antechamber of the art of speeches (269d6-8 $=$ LM fr. R6a), even if they are dexterous in composing them. Enumerating components of this dexterity in 268c7-d1, Plato certainly alludes to Thrasymachus' art, described in similar terms earlier on (in the passage commented upon by Hermias, see [G1]); these components are - in addition to the ability to present a small event in a long story, and a large one in a terse story, which is considered characteristic to Teisias and Gorgias as well ([E4]) - [H4:] the ability to create speeches that would be plaintive or amusing, terrifying or threatening, at will (cf. [B2], [E]). [H5:] In his sixth and last reference to Thrasymachus, Plato sums up: if Thrasymachus or any other person is serious about practising the art of rhetoric, which relies on developing a conviction (peitho) in the souls of the listeners, he must first precisely (pase akribeia) describe the nature of the soul $(271 \mathrm{a} 2-6=\mathrm{LM}$ fr. R6b). The sources do not report Thrasymachus attaining such a triumph; they only confirm the general akribeia of his thoughts and speeches ([E4]). Here, Plato's critical and slightly perverse tone suggests that Thrasymachus was truly not interested in psychology, even though he was adept at moving the emotions of his listeners. It was to be Plato's Socrates that would fill this lacuna with his own lectures on the soul, both in the Phaedrus, referring to the historical Thrasymachus, and in the Republic, presenting a polemic with a thesis posed by the Platonic Thrasymachus.

The above references to Thrasymachus found in the Phaedrus indicate that Plato was truly impressed with the sophist; after all, Plato put him at the head of the great sophists, crediting him with the greatest force (sthenos). [I:] Dionysius, an expert on rhetoric, goes as far as to state that Plato adopted some elements of Thrasymachus' style (loftiness combined with simplicity, Dem. 3 = DK fr. B1, v. 23-5). In the Byzantine Suda, which is probably an 
adaptation of older encyclopaedias, we find a sentence which is telling (despite being damaged): in the context of Thrasymachus' achievements in the field of rhetoric, it is stated that he was a mathetes [?] Platonos tou philosophou, with Kranz's addition - mathetes [on Teisiou, kathegetes de] Platonos (DK fr. A1) - "[being] a disciple [of Teisias, and the teacher of] Plato." The tradition linking Thrasymachus and Plato goes back to the $4^{\text {th }}$ century BC: in the fragment from a play Nauagos by Ephippus (fr. 14), dating most probably from the late 360/ early 350 $\mathrm{BC}$, the figures of Plato and Thrasymachus are linked as the object of the same comedic ridicule. $^{25}$

All these testimonies make it less surprising that Thrasymachus was that great sophist among the great sophists (Gorgias, Hippias, Prodikus, and Protagoras) to whom Plato devoted the most attention (even when measured solely by the number of pages of dialogue). It is to him that he ascribed a thesis with which he is to contend for the ten books of the Republic, shaping the content and the method of his own philosophy as he does so. ${ }^{26}$

\footnotetext{
${ }^{25}$ The fragment is given by Athenaeus (11 509d-e): there, Plato is additionally associated with Bryson of Heraclea, about whom earlier Athenaeus wrote, quoting Theopompus of Chios, that Plato derived "many thoughts" from his teachings (11 508d). Thrasymachus and Bryson are linked by demanding payment for their teaching (cf. [H3]). It is unclear whether Plato was connected with Thrasymachus in the same way as with Bryson, i.e. by "many thoughts."

${ }^{26}$ Socrates debates directly with Thrasymachus in Republic 1 . Had that been all, we would have another short Socratic dialogue of an aporetic nature - in keeping with the hypothesis of an originally separate sketch or dialogue (called Thrasymachus by K.F. Dümmler), later incorporated into the Republic (in its earlier version called the ,proto-Republic"), accepted, following Schleiermacher, mainly by German classicists of the $19^{\text {th }}$ and $20^{\text {th }}$ century, and today, by Thesleff $1967,14 \mathrm{n} .34,95,111 ; 1982,256-9$ (for an outline of the earlier debate, see Friedländer 1957, 283 n. 1; modern standpoints at Blondell 2004: 165). Regardless of the credibility of this hypothesis, Plato decides to continue the Thrasymachean theme: after a clash with Thrasymachus, his Socrates is unhappy with the results of his elenctics; his dissatisfaction is reinforced by Plato's brothers Glaucon and Adeimantus, who throughout the first half of Book 2 not only represent Thrasymachus, but actually point to a meaning of his thesis that would force Socrates to take up the topics of the paideia, psychology, ethics, epistemology, and ontology, in a word: make him point the way for philosophy. Hence Plato has his Socrates discept TT until the end of the dialogue, in the meantime allowing Thrasymachus to put in a few words or citing his name $(450 \mathrm{a}-\mathrm{b}$, $498 \mathrm{c} 8,545 \mathrm{a} 8,590 \mathrm{~d} 2$, with an allusion to Thrasymachus in 493b) - as if to remind the reader that it is his view that is being discussed (this is stressed by, e.g., Wedgwood 2017, 54, 60-61; Anderson 2016, 151). If, therefore, the dialogue Thrasymachus had been included into the later books of the Republic as an introduction (so Thesleff 1982, 256; Dornseiff 1941, 111 - the latter reference after Friedländer 1960, 440 n. 1), the references to Thrasymachus in those books would have been unclear unless Plato had constantly borne in mind what he had written in the "Thrasymachean Book."
} 


\section{A close encounter with Thrasymachus}

Plato arranged for Thrasymachus and Socrates to meet at Piraeus at the time of the festival of Bendis, the Thracian goddess of the moon and hunting introduced to Greece for the first time then. This happened on a hot day $(350 \mathrm{~d} 2)^{27}$ at the time of the Peloponnesian War during which - as reported by Thucydides from various areas of the Greek oikoumene - the positive, morally uplifting quality of justice was being replaced with the profit of the stronger side. ${ }^{28}$ The witnesses to that meeting include nine historical figures mentioned by name and a group of unnamed persons (327c3); among the former are its hosts, the metic Cephalus and his three sons (Polemarchus, Lysias, and Euthydemus), one of the richest families of Attica at that time. Most probably each and every reader of this dialogue who was contemporary to Plato knew - if not from their own recollections, then from a speech written by Lysias soon after the War, in which he related those tragic events (Lys. 12) - that towards the end of the War this family would fall victim to the cleansing of Athens of "unjust men" conducted by the city authorities.

Plato reports the reason why Socrates went down to Piraeus: to pray to the new goddess and to watch the celebrations $(327 \mathrm{a} 2-3) ;{ }^{29}$ he does not report Thrasymachus' reasons for being there. When Socrates entered the house of Polemarchus - who had stopped him was already on his way back to Athens and invited him to a communal waiting for the night ritual (pannychis) - he saw Thrasymachus already there, sitting with Lysias, his brother Euthydemus, the equally rich Charmantides, Cleitophon, and Cephalus. They would be joined by others, leading Socrates with them; one of those would be Niceratus the son of Nicias. The historical Thrasymachus might well have found himself in this company; he probably knew at least three of the men present. In the Phaedrus, Plato links him with Lysias as a professional colleague ([H3]), and Lysias himself in one of his speeches describes an event in which Thrasymachus participated ([E1]); in the first sentence of the allegedly pseudo-Platonic dialogue Cleitophon, Cleitophon is mentioned as one who preferred the company of Thrasymachus to that of Socrates (see also Kleitoph. 410c1; cf. [C1]); Niceratus - known to Thrasymachus from at least one unsuccessful

\footnotetext{
${ }^{27}$ Thargelion 19 (in May-June). See Schol. Resp. 327a; Procl. In Tim. 1.26.14-15.

${ }^{28}$ Tkd. I 73, 75-6, II 63, III 9-13, 40, 44, 82-3, IV 60-5, VI 18, 83, 85, VII 55, VIII 48; esp. V 89-107, 116: the Athenians' genocide demonstration of the universal right of justice as the profit of the stronger - against the Melians. It must be remembered that Thrasymachus' native Chalcedon was one of the many poleis painfully subjected to the rapacious policies of Athens.

${ }^{29}$ Elian FH 2.13 confirms that Socrates was in the habit of going down to Piraeus, but cites a different reason: to watch Euripides "every time he participated in a competition there."
} 
poetical competition $([\mathrm{E} 3])^{30}$ - was remembered by Xenophon as able to recite Homer in its entirety from memory (Conv. 3.5-6), and in Plato's Laches (200c-d) mentioned as - just like Cleitophon - unwilling to be taught by Socrates. It might be added that Charmantides chose Isocrates to be his teacher. ${ }^{31}$ In the context of the limited source material regarding Thrasymachus, it is indeed curious that out of all the group waiting together for the night ritual - all men "embroiled in the social and political life of Athens" 32 - the largest scope of source material pertains to Lysias and, after all, Thrasymachus. Thus, it only remains to confine ourselves to saying that in this company - together with Thrasymachus and Plato's brothers Socrates to await the night-time ritual of Bendis. At the meeting and the preceding supper (deipnon, 328a8) the guests would partake of a conversation which during Socrates' debate with Thrasymachus would turn out to be so fulfilling that it would make the viands redundant (354a10-b3).

Aware of Socrates' taste for conversation with men claiming to possess some knowledge, we cannot be surprised that Thrasymachus - who not only went down in history as having an exceptional gift of persuasion and combative speaking, but was commemorated by the funerary epitaph: "Profession: wisdom" ([C2]) - did not dodge the blade of Socratic elenctics. When conversing with the great sophists, it was Plato's Socrates that initiated this process. ${ }^{33}$ The situation is quite the opposite in the case of the Chalcedonian ${ }^{34}$ and even this difference seems an element of creation for the colourful, saucy character Thrasymachus - and thus also of Plato's competition with Lysias, a master of the art of ethopoiia in court speeches. Plato certainly achieved a comical effect by mocking the temper and the rhetorical method of historical Thrasymachus ([A], [D3], [E], [G1]): he made him sit tolerably silently for quite a long while - like a wild beast, restrained by others, who wished to listen to all the exchange

\footnotetext{
${ }^{30}$ See also White 1995,325 n. 61.

${ }^{31}$ White 1995, 326; cf. Nails 2002, 89-90.

${ }^{32}$ Schofield 2006, 174. If "[s]ymbolism is shorthand for an argument" (Benardete 1989, 9; similarly in the context of the Laws, Schöpsdau 1994, 102; more guardedly Nails 2002, xxxviii), in the case of the Republic this very complex and detailed setting does not led itself to coherent reconstruction (see Nails 2002, 324-6). Cf. Thesleff 1982, 257, who, arguing that Republic 1 is separated from the rest (see n. 26 above), has to claim that "the addition of Thrasymachus of Chalcedon to this company looks like a rather artificial trick."

${ }^{33}$ With Protagoras (Prot. 316b1), Gorgias (Gorg. 447c1), Prodicus (Prot. 339e6), and Hippias (Hipp. Mi. 363b6).

${ }^{34}$ Also Polus and Callicles are the first to initiate a conversation with Socrates (Gorg. 461b3, 481b6), as they, similarly to Thrasymachus, are irritated by his manner of conducting the conversation with their predecessor, and are of an opinion close to TT.
} 
between Socrates and the hosts (Cephalus and Polemarchus) - before he allowed him to pounce on Socrates and Polemarchus. And then, after Thrasymachus had filled them with fear and horror, criticised their pointless and barren talk (336b1-d4), and heard their pleas for mercy (eleeisthai, 336e10) - he "clearly and precisely" (cf. 336d2-3) gave a short definition of justice (338c1-2); before - as befits the historical Thrasymachus ([H3]) - demanded payment for it (337d6-7). A claim to having a remedy, or an answer, to a serious political problem is the leading motif of the prooimion of the historical Thrasymachus, intended to draw the attention of the addressees of his presentation ([D3]). Precision, brevity and compactness of thoughts are the most admired features of his style ([E4]), which Plato highlights in the very terse TT. Manipulation of the listeners' feelings is the Chalcedonian's ability underlined by Plato in the Phaedrus and confirmed by Hermias ([G1], [H4]). Finally, the status of a specialist on arousing pity is given him by the title of his work, Eleoi ([B2], cf. [G1]); fittingly, in the comic scene of the Republic he is asked to show some of what he teaches. Yet are we to believe that Socrates, of all people - Socrates, who is not only aware, as any Athenian active in public life would be, of Thrasymachus' rhetorical sthenos ([G1]), but also experienced in debates with the sophists - allowed himself to be frightened by him, and that the Chalcedonian, for this one time, does not feign indignation? Let us review the scene that has evoked these emotions, since it creates a context that allows us to better understand the manner in which Plato treated Thrasymachus and the TT ascribed to him.

\section{The Forceful and Angry Thrasymachus}

The practical power of refuted theses: the ungraspable wisdom

It is the scene of the conversation between Socrates and Cephalus - the opening scene of the dialogue in Cephalus' house - which is, in effect, an act of transferring a double heritage: material assets go to Polemarchus and his brothers, moral values go to the generation of Polemarchus and Plato's brothers. This would be a serious act in itself: it could, in fact, be linked to Thrasymachus' appeal to the Athenians to listen to what the elders have to say ([D5]); but in Plato's scenery it is a comic act or, as a result, a "serio-comic" one (spoudaiogeloion). ${ }^{35}$ Now, Cephalus is old and rich; these dominant traits provide the theme for Socrates' first questions: what is old age like and how does wealth conduce to the bearing of old age easily?

\footnotetext{
${ }^{35}$ On the type of spoudaiogeloios crucial not only to the Attic comedy, but also to Platonic philosophy, see Bromberg 2018, 31-2.
} 
He learns that Cephalus - who is happy with his life and, in his own view, is honest and respectable (329d4, 330a6), and who finds solace in the wisdom of Sophocles, Themistocles and Pindar, the sages of his generation - finds wealth to be a source of moral profit. Cephalus soothes the fear of punishment (dike) meted out there for acts of injustice (adikemata) committed here, which so often plagues old people, consoling himself with the capability of paying a financial compensation for inadvertent lies and trickery, and of making sacrifices to the gods and paying debts to men (330d5-331b7). For the rich man, this is a convenient morality: it allows him to adjust his sense of justice to his own needs, abilities, and advantages; for the not-so-rich Socrates, it is indeed coherent, since it allows him to easily detect the concept of justice (horos dikaiosunes, 331d2-3) it contains: "speaking the truth and giving back what one takes" - but no more than that. But, in his perception, it is "a thing more precious than a great deal of gold" to know what justice is (336e 7-8). Hence Socrates focuses on the legacy he may get from Cephalus and easily notes that it is not perfect; after all, it is not always advisable to speak the truth or to render back what is due (331c5-9). Cephalus agrees with this point of view and thus the danger arises that his moral treasure may break to smithereens under the blow of the archetypal Socratic elenctics; but Polemarchus immediately catches it, to protect it in the name of his father (331d4). No wonder; since he and his brothers are heirs to the wealth (330b6), the sense of justice resulting therefrom is his treasure also. The protagonists of the dialogue cannot know - but its first readers probably do - what would happen to this wealth, and to Polemarchus himself, in 404: the former would be confiscated and the latter would die. What may interest the first readers in this dramatic situation is the value of their own part of the inheritance: the specific perception of justice. Cephalus himself is happy with what he gains: peace of mind before death. Even though he had declared his willingness to converse (328d4), he forgoes further conversation with Socrates, passing on the logos on justice to Polemarchus as his heir and to Socrates; he takes his leave, wishing to offer sacrifices to the gods. His accompanying smile (331d9) and the ease with which Plato allows him to walk away, reinforce the pathetic ridiculousness of this scene. No-one follows him; the guests stay engrossed in what remains after he is gone, that is, the open question of what should be given back, and to whom. Advice to listen to the older generation living in the patrios politeia, offered by the historical Thrasymachus, is not an easily applied remedy.

To protect his inheritance, Polemarchus reaches for a different cure than a religious ritual: he refers to the authority of the poet Simonides, who together with Homer and Hesiod formed the canon of the moral values taught at schools in the $5^{\text {th }}$ and $4^{\text {th }}$ century BC. Thanks to him, he may complement the unspecified "what and to whom" with the clear (especially in the 
times of war) "good to friends, evil to foes," thus confirming the worth of the moral legacy he received from Cephalus. ${ }^{36}$ Socrates, in turn, cannot determine what the "wise and inspired man" (331e6) had really said, although it was probably both wise and inspired. All he can do in the absence of the proponent of a given view is to investigate the worth of this part of his legacy that can be understood and accepted. During this investigation he creates a string of more or less surprising analogies to skill (techne), and of consequences contrary to the common sense of decency, all relying on the justice as per Cephalus and Simonides, that is, rendering to each his due: if justice is to be valid also in peacetime, it will transpire that - since an expert is a more useful and better partner than a just man - "justice is useless in the use of each [thing] and useful in its uselessness" (333d10-11); and if the wartime "friend/foe" relationship is substituted with a peacetime one - so much desired by the post-Peloponnesian War generation - in the form of "bad/useful-good" (poneros/chrestos-agathos) present in any society, then considering the human error factor in assessing other people's quality - it may turn out that "it's just to do harm to men who have done nothing unjust" (334d5-6). The general conclusion is that the perception of justice as the distribution of good and evil (harm) within any dichotomy (whether the "friend/foe" or the "good/bad" one) leads to a nonsense: the just men, rendering to foes/bad men what is their due - i.e. harm - make them unjust using justice, because the real harm to a man is to deprive him of the "human virtue" that justice obviously is $(335 \mathrm{c} 1-\mathrm{d} 1)$. This unwise conclusion reveals that it is impossible to grasp the wisdom of the old sages $(335 \mathrm{e} 4)$ - the sages cannot, after all, be interpreted unwisely. What remains is to fight in defence of the ungraspable wisdom against those who, citing the authority of the sages, ascribe an erroneously interpreted justice to them (335e $7-9)$.

Polemarchus is ready to join in this fight (335e11). But just as he is unable to perceive the future fate of Cephalus' wealth he inherits, from inside the dialogue, he cannot perceive that the indecently absurd concepts which Socrates has derived from the ungraspable justice as proposed by Cephalus and Simonides will come true in the fate that awaits both himself and Socrates. They will both become a glaring example of how the so-called "just men" mete out injustice to those who had not committed an injustice, and call this justice. ${ }^{37}$ This is Plato's

\footnotetext{
${ }^{36}$ On the opposition "helping friends/harming enemies" as "the code lying at the heart of Greek popular ethics," see Blundell 1989. See also Friedländer 1957, 51: this is a "Volksmoral" preached by Solon. On Cephalus as a proponent of traditional values inherited by Polemarchus, see Blondell 2004, 174-7.

${ }^{37}$ Lysias reports (Lys. 12.5) that the family of Cephalus fell victim to the purge instituted by the aristocratic fraction to cleanse the state of "unjust men" (ton adikon) in the name of justice and the law. In the Epistle 7, on the other hand, ascribed to Plato, Socrates is called "the most just of men then living" (dikaiotaton, 324e2), who was sentenced to death by the democratic authorities - this time in the name
} 
knowledge, realising that although some thesis or definition may turn out weak/bad (poneros, 334d7) in terms of dialectics, it may still surface in the real world; it does not always suffice to refute an argument in order to take away its practical power. ${ }^{38}$ TT will have a similar nature to a hydra: the punches of Socratic elenctics will seem to demolish it, and yet it will keep raising its head in political realities. Plato seems to share this knowledge with his Socrates and his Thrasymachus: with the former, when Socrates, after the battle with Thrasymachus (from which, according to the rules of elenctics, he emerges victorious), will nevertheless admit that he gained so much from it that he no longer knows a thing (354b9-c1), and with the latter, when Thrasymachus first angrily accuses Socrates and Polemarchus of talking nonsense and deferring to one another (336b8-c2), and then, as he himself, and his thesis, will find themselves under attack of Socratic elenctics, he takes its punches with an increasing apathy to finally state that "it looks like it" only according to Socrates' argument (kata ton son logon, 353e12). Thrasymachus will leave his wisdom, intact, to himself, at least at this stage of the dialogue. ${ }^{39}$ Whether in the latter, non-elenctic part of the dialogue Plato in any way incorporates that wisdom into the wisdom of his Socrates is a question pertaining to the links between Book 1 and the others. At the current stage of the proceedings - all taking place on the festival in honour of the dark goddess of the hunt - it may be stated that the anger of Thrasymachus, who

of their sense of justice and the law - under "the most unholy" charge (anosiotaten aitian, 325b7). In the Republic, an allusion to his trial is discernible in the conversation with Thrasymachus in 337d1-5.

${ }^{38}$ The nonsense expressed in $333 \mathrm{~d} 10-11$ is, in turn, an echo of the Athenians' practical observation as they implemented a policy of force against the Melians: justice exists only when the forces are even; otherwise the stronger side will profit (Tkd. V 89).

${ }^{39}$ Plato's Thrasymachus expresses the standard evident in the fate of Socrates and the sons of Cephalus (see note 37) in the explication of his thesis in 338e1-6: every type of authority marks out some people as "unjust" (adikountes) according to the criterion of its own advantage (as says also an anonymous Athenian in Leg. 714d5-7). If, as argued by White 1995, the historical Thrasymachus came to Athens in 407 as an envoy from Chalcedon to prevent - after the abortive revolt in his native city in defense of its political autonomy - "brutal reprisals" (p. 317) by imperialistic Athens, most probably - as a representative of the weaker side - he would not be a supporter of the policy of force ("justice of the stronger"), but a diplomat aware of not only its practical application, but a tragic consequences for the weaker party, which he wants to prevent (nine years earlier the Melians fell victim to the Athenians' rapaciousness; two decades earlier the Mytilenians narrowly escaped it). If TT, as argued by Bloom 1968,327 , reflects "the city's action," the obvious question to ask in the context of White's hypothesis is: which polis would Plato's Thrasymachus represent, the imperial Athens or the weaker Chalcedon? The more probable we consider the notion that Thrasymachus, a patriot and diplomat of Chalcedon, could not defend, in front of the Athenians, their "politics of force" if he had been its victim himself, the more probably it is that Plato's Thrasymachus, too, has reasons to apply the name of "balderdash" (phluaria, 336b8) to Socrates' elenctic refutation of theses that nonetheless operated, and would continue to operate in the political reality. Cf. [C] and White's commentary (pp. 318-9), who makes the suggestion that Thrasymachus urged resistance to the barbarian power of the Macedonian king (see $\mathrm{n}$. 15 above). Compare Putterman 2000, 82-3; Blondell 2004, 177-9, 183-4, 192-4; Anderson 2016, 154. 
is compared to a wild beast (therion, 336b5), ${ }^{40}$ is justified and sincere. ${ }^{41}$ The effect of its genuineness is reinforced not only by Plato's Socrates, who three times states that he is afraid (336b7, d6, e1-2), but also by the manner in which Plato makes Thrasymachus proclaim his position.

\section{The Ridiculous "How"}

Thrasymachus betrays a certain emotional and intellectual volatility that seems neither proper nor effective as a rhetorician's trick. ${ }^{42}$ Plato marks it by means of five successive dramatic ploys.

(1) Thrasymachus is shown as interfering in the debate.

Thus shown, he dominates the background to the action, where he "many times" (336b1) wants to interrupt Socrates' conversation with Polemarchus (unsuccessfully, but only because of the other men's reaction) and speaks out in its course, warning all and sundry that Socrates will certainly use the ironic tricks he is so familiar with, that is, while asking questions and refuting answers he will give no answers himself (337a4-7). This is not the behaviour of a selfcontrolled rhetorician skilled in guiding the emotions of others, but rather that of an irritated listener who finds it difficult to control his own emotions. The impulse he is unable to resist is the question put forward by Socrates in reference to Cephalus' legacy: if to speak the truth and render back what is owed are "neither justice nor the just," then "what else would one say they are?" (336a9-10). To the readers of the dialogue, this is an encouragement to think differently than hitherto, but not a suggestion as to how. To Plato's Thrasymachus, this is the impulse that prompts him to attack, all the more powerfully because he not only knows the "how," but he is

\footnotetext{
${ }^{40}$ Significantly numerous passages where Thrasymachus is shown as a wild beast are enumerated by Blondell 2004, 56.

${ }^{41}$ I think I am not in disagreement here with Anderson 2016, 154-5, when he argues that Thrasymachus objects to the unproductive method of Socratic eristic. Differently Mitchell 2003, 8, in whose view Thrasymachus is provoked not by the ineffectiveness of Socratic elenctics in reference to some theses, but by the doctrinal assumption made by Socrates and Polemarchus that it is sensible to ask whether it is just to tell the truth and pay back debts, because this question presupposes the objectivity of justice. Let it be noted, however, that also the historical Thrasymachus admits to the objectivity of some values, as contained in the praiseworthy motto of patrios politeia ([D4]). This point is also stressed by Havelock 1957, 233-9.

${ }^{42}$ Despite Blondell 2004, 180 (following Reeve 1988, 9-10): Thrasymachus lets in the "fresh air."
} 
also certain that his "how" is "different" and "more beautiful" (337d1-2). But before Plato allows him to present that "how," and then assesses its advertised worth, he makes us witness Thrasymachus move his listeners to fear: the rhetorician behaves like a wild beast wanting to tear the victim apart (336b5-6; [H4]). The less probability there was for the men who knew Thrasymachus to see such a scene in real life, the greater was its comical effect. This is the true face of Thrasymachus - Plato is kidding - until now hidden under the mask of a self-controlled rhetorician that guides the emotions of others. To show him in a comic distortion, Plato made Thrasymachus wear the mask of an angry beast $([\mathrm{F}]) .{ }^{43}$

\section{(2) Thrasymachus is hilariously illogical.}

In his first speech, where he vents his anger, Thrasymachus betrays the turmoil in his thoughts. Roaring in the midst of all the listeners (eis to meson phthenxamenos, 336b8), he asks Socrates: "If you truly want to know what the just is [...] answer yourself and say what you assert the just to be" (336c2-6). As soon as Socrates shakes off the shock of Thrasymachus' attack, he promptly points out to him that lapse in logic and commissions from him a paid lecture on what justice is (337e4-5). Trusting Dionysius, who praised Thrasymachus' perfection in expressing his thoughts ([E4]), we perceive another comically deformed caricature in the above exchange.

\section{(3) Thrasymachus' charge against Socrates is ridiculously inconsistent.}

Asking Socrates to first answer the question as to what Socrates does not know, Thrasymachus tells him what he expects from him, or rather, what he forbids him to do: And see to it you don't tell me (hopos moi me ereis) that it is the needful, or the helpful, or the profitable, or the gainful, or the advantageous (to sumpheron); but tell me clearly and precisely (saphos kai akribos) what you mean. (336c6-d3)

The comic effect comes out immediately when Thrasymachus, so admired by Dionysius for his precision (akribeia) and clarity of style ([E4]), formulates the TT: faced with Socrates' inability to answer in general, and in particular to answer in a manner a priori excluding all that

\footnotetext{
${ }^{43}$ Conversely Taylor 1966, 267: "the violence and exaggeration is presumably a genuine characteristic of the actual Thrasymachus."
} 
seems true to him, Thrasymachus states exactly what he forbade his opponent to state: justice is "the advantage (to sumpheron)" - with the addition: "of the stronger" (338c2).

There is no basis for the assumption that the historical Thrasymachus supported TT; but there are reasons to recognise the above-mentioned scene of logical inconsistency as an allusion not to his views, but to an authentic rhetorical strategy not mentioned in non-Platonic testimonies: ruling out the obvious answer a priori. Thrasymachus' logical inconsistency, which on the level of the dialogue's dramaturgy attests to a certain emotional and mental volatility, i.e. unfeigned anger, is stressed by Plato with such force that it is difficult to escape the impression that he presents here, in a caricature, an authentic trick of the combative rhetoric of the historical Thrasymachus; then, TT would constitute a perfect tool of comic exaggeration. The scene at $337 \mathrm{a} 8-\mathrm{c} 10$ is symptomatic of this: by reducing that rhetorical strategy of Thrasymachus ad absurdum in a mathematical example, Socrates mocks him by quoting his phrase: "see to it you don't tell me (hopos moi me ereis) [...] that it [twelve] is two times six" (337b1-2). In answer, Thrasymachus does not renounce his method, but aptly notes that the two things, a definition of justice and a mathematical calculation, are dissimilar (337c2). Let it be also noted that Socrates has hitherto not given any definition of justice, all the more one that would be as certain as a mathematical calculation. In this respect, his argument is defective. If we assume that Plato is not trying to accuse Socrates of a logical weakness - and thus if we do not focus on his faulty punch, but on what dominates in this scene - it will turn out that it is a well-presented rhetorical trick and a recurring phrase that accompanies it (this will be cited again in a similar form hopos meden erei in 337e6-7 and recalled in 339a 7-8), ${ }^{44}$ illustrated in caricature by means of the TT. This caricature turns all the more vivid when Socrates admits to holding a powerful conviction (doxa) about justice which Thrasymachus a priori forbids him to mention. This is the assumption that justice is some advantage. What is more, Socrates adds that he would not be surprised if he continued to hold it even after its examination (337c9-10; repeated in 339b4). ${ }^{45}$ And indeed, a negation of this conviction is nowhere to be found in the entire dialogue.

\footnotetext{
${ }^{44}$ An allusion to it is discernible also in $346 \mathrm{a} 3$ and 350e5, where Socrates, by asking Thrasymachus not to answer against his conviction, indicates that he himself does not use Thrasymachus' method. This parodic tone is missing in the arguments of some commentators (e.g. Anderson 2016, 155-6, referring to Welton 2006, esp. 293-305) who argue that here Plato is emphasizing a contrast between Socrates and Thrasymachus: the former thinks justice is as objective as mathematics, the latter cannot accept such an identity.

${ }^{45}$ In the pseudo-Platonic Cleitophon (409c2-3) terms describing justice that were a priori ruled out by Thrasymachus in Rep. 336d1-2 are cited and accepted by the followers of Socrates.
} 
The impression made by Thrasymachus and the features of his exceptionally powerful rhetorical style seem more important than what he has to say - at least at this stage of the dialogue. Showing the probably authentic figure of Thrasymachus in a distorting mirror, with a comically exaggerated description of his rhetorical techniques - that is, staging a strange, contrived form for Thrasymachus to express the TT - allows Plato to create a suitable contrast, thanks to which he can present his own form of expressing TT, and his own attitude to it, in an appropriate light. In other words, Plato seems to use the extraordinary sthenos of the historical Thrasymachus as a tool for expressing his own view on the view ascribed to him.

\section{(4) Thrasymachus' boast.}

That Thrasymachus is treated instrumentally becomes clear in the following scene, where - after Socrates lays bare his rhetorical trick relying on prohibiting the obvious answer a priori even if it is true $(337 \mathrm{c} 1)$ - the famous combative speaker Thrasymachus ([E]) defends himself with the boast that he can give "another" (heteran) and "better" (beltio) answer on the topic of justice "besides all these" (para pasas tautas peri dikaiosunes, 337d1-2). As proof, he gives the most precise definition of justice possible: "the advantage of the stronger" (338c1-2). Being composed of just two words, it seems to be another distorted exemplification of the historical Thrasymachus' gift for terse expression ([E4]).

\section{(5) The disgusting Socrates}

Passage 338c4-339b2 supports the assumption that Plato presents a caricature not of the content, but the style of Thrasymachus' teachings. It suggests that Socrates is not shaken by the meaning of the TT, but by the fact that it is advertised as "another" and "better." He may, after all, know its content, albeit expressed differently, from such men as Polus, Callicles, Antiphon or Critias. This focus on the style of the rhetorician - a man who was known to the Athenians as the one who pretended to have, and be able to offer, an exceptional remedy to the political crisis ([D2-3]) - is seen in the two following scenes. First, when Socrates asks naively - in Thrasymachus' view: "disgustingly" (338d3) - whether "the stronger" is a man like the pancratist Polydamas, whose advantage from eating beef means that this meat is advantageous also to us, the weaker ones (338a5-d2), and thus accuses Thrasymachus of a lack of clarity, even though - or perhaps: especially - the latter required Socrates to speak clearly and precisely (compare 338d5 with 336d2-3) and thus suggested he himself valued, and made use of, these 
requisites of beautiful speech. Then, when Socrates, following Thrasymachus' explanation that in the word "stronger" he has condensed every "established ruling body" (339a1) regardless of the political system, suspends the trueness of this explicated contents and states a straightforward accusation against Thrasymachus' rhetorical strategy (339a5-9). In other words, even if the "disgusting Socrates" does not ridicule the motif of the "gastric power" displayed in front of the king of Persia from the speech of the historical Thrasymachus ([E2]), ${ }^{46}$ he certainly makes it clear that he is struck not as much by the content of TT, but by the rhetorician's desire to gain fame by giving "a very fine answer" (apokrisin pankalen, 338a7) by means of denying, "at least to him" (emoige, 339a6-8), the right to speak what the rhetorician says himself, only adding "of the stronger." Here, the terse Thrasymachus bridled: “A small addition, perhaps" (339b1). Thus, by highlighting just one word from his different and better definition of justice - "the stronger" - he has brought this terseness of style to the extreme; answering Socrates' request to state things more clearly, he ultimately condensed his definition to just one word. This one-word quintessence - a caricature of clarity and precision - illustrates all the qualities of Thrasymachus' style confirmed by the testimonies: [E1-3] combativeness as his own feature and as a motif in his speeches; [E4] - conciseness and concentration of thoughts; [G1] - the sthenos of his art; [H4] - the ability to manipulate the listeners' feelings, including moving them to fear.

Thus the issue of how the rhetorician presents and adds value to a certain thought comes to the fore of the dialogue. Thrasymachus impressively stretches his muscles, claiming to be saying different, better, and important things in an as clear and as condensed form as possible - delivering them, so to speak, in one powerful, surprising punch. If, therefore, in keeping with the surviving source material, the indicator of the historical Thrasymachus' greatness and originality was not what he said, but how he said it, then these are also the features that Plato focuses on. Although he turns them into a caricature, he lets the readers recognise their authentic owner, for whom Dionysius certainly felt sincere regard ([E4]), and whom Plato ([I]) may have admired as well, even though not without irritation over the efficacy of his techniques of persuasion despite the lack of deeper psychological reflection ([H5]).

\footnotetext{
${ }^{46}$ As Pausanias reports (6.5.7), Dareius persuaded the big and strong Polydamas "to come before his presence at Susa. There he challenged three of the Persians called Immortals to fight him - one against three - and killed them" (trans. W.H.S. Jones). This parallel is also mentioned by White 1995, $325 \mathrm{n}$. 58 .
} 
But will the content of TT truly appear different and better? This question, provoked less by the meaning of TT than by Thrasymachus' rhetorical manner and the form of presenting his "very fine answer," points out the course of the subsequent dialogue.

TT as "Another" and "Better" Teaching

The unclear "what": their and our problem with TT

Until now, the clash between Socrates and Thrasymachus (336b1-339b2) had been at the stage of mutually revealing the opponent's character, moving into positions and paying tit for tat. The ad personam remarks they level at one another indicate that Thrasymachus and Socrates know each other inside and out, and they are perfectly able to predict one another's polemic strategies: Thrasymachus openly states his familiarity with "that habitual irony of Socrates" (337a4-7, e1-2); he knows that his elenctics leads to the refutation of the opponent's argument and does not offer a positive argument in return $(336 \mathrm{c} 4,337 \mathrm{e} 2-3)$; he can perfectly (eu) foresee Socrates' reaction to his subsequent public speech (demegorein, 350d10-e1; cf. [D1]). ${ }^{47}$ There is no basis for doubting in the reliability of this perception of the historical Socrates by some group of his contemporaries (at least such as those rhetoricians who vied with him in the field of paideia, including Thrasymachus) $;{ }^{48}$ neither is there a reason to doubt, in turn, in the reliability of the image of the historical Thrasymachus as rendered by Plato's Socrates. He calls the rhetorician sophos directly and more than once apes his combative trick (337a8-b5, e6-7, 339a7-8, 346a3, 350e5). Indirectly, through the description of his own reaction to Thrasymachus' anger, he shows him in the distorting mirror of comedy as a bombastic manipulator of the listeners' feelings. These opposing images of the two figures are completed by the definite and unchanging positions they voluntarily assume: Thrasymachus shows and teaches for a fee, while Socrates seeks, errs and verifies what has been shown to him. ${ }^{49}$ If the hitherto effect of their mutual attacks on each other's chosen method of conversation is some kind of balance of power - gauged most probably by those who had not

\footnotetext{
${ }^{47}$ See also White 1995, 310-11 n. 14.

${ }^{48}$ See Tht. 150c4-7; cf. Ferrari 2013, 11-31, esp. 23-5.

${ }^{49}$ Apodeixis/endeixis and didache of Thrasymachus: respectively 337d1, 344e7 and 338a3 (cf. [D4]); skepsis (skopeo, skeptomai) and zetesis of Socrates: respectively $336 \mathrm{e} 3$ (with the probability of error), $337 \mathrm{c} 9,339 \mathrm{~b} 2-6, \mathrm{~d} 5,345 \mathrm{c} 1,347 \mathrm{e} 2,348 \mathrm{~b} 3,349 \mathrm{a} 5,350 \mathrm{e} 11,351 \mathrm{e} 7,352 \mathrm{~d} 5-8,353 \mathrm{~d} 3,354 \mathrm{~b} 5$ and $336 \mathrm{e} 6-7$, $368 \mathrm{c} 7$.
} 
yet decided which teacher to choose $\mathrm{e}^{50}$ - at this stage of the dialogue the point of greatest difference between them is their differing approach to the definition (horos) or thesis: for Thrasymachus, it is the crowning attainment, after which he expects his fee, for Socrates, it is the starting point of an investigation, i.e., a hypothesis. ${ }^{51}$

In spite of the whole confusion and emotional turmoil (interruptions and anger on the part of Thrasymachus, fright and a plea for mercy on the part of Socrates), what Thrasymachus demonstrates can be reduced to one word: "the stronger" (kreitton, 339a9). Since the power of Thrasymachus' rhetorical art lies in conciseness and concentration, which give his "demonstration" (apodeixis) the quality of being different and better, no wonder, then, that when Socrates formulates the topic of his enquiry (skepsis), he uses the same word as in the title of Thrasymachus' rhetorical handbook, Megale techne ([B1]): he says that it is necessary to determine whether "stronger" is truly such a great addition (megale prostheke) to the definition of justice as an advantage, which Socrates does accept (339b2).

If those episodes were intended to, and did, amuse the first readers of the dialogue, they did so most probably because the readers recognised their allusions to historical figures. ${ }^{52}$ But there is also a serious theme among them, smoothly woven into the caricature of Thrasymachus' style and not developed directly afterwards, which - by giving the whole the character of a spoudaiogeloion - indicates that the aim of the dialogue is something more than merely making fun of Thrasymachus'sthenos. It is the moment when Plato makes Thrasymachus ask the question as to what punishment would be meted out to Socrates should Thrasymachus' own definition of justice prove truly different and better. The question of "what punishment do you think you would deserve to suffer" (ti aksiois pathein, 337d2) not only brings to mind the question asked of Socrates during his trial (Ap. 36d1-4), but also in both cases Socrates, to the judges' irritation, expects good things to come to him: from the Athenians, free meals at the Prytaneion, from Thrasymachus - teachings that would be different and better (337d1-5). Much as this theme - a serious one, as it alludes to the unjust sentence of death meted out to

${ }^{50}$ Cleitophon and Niceratus are known as those who chose Thrasymachus. Polemarchus, in turn, converted to philosophy, as mentioned by Plato through the mouth of Socrates in the Phaedrus (257b3-4); thus, it was Socratic philosophy.

${ }^{51}$ TT as a horos of justice: in answer to Socrates' question about the horos in 331d2, which he makes more precise by means of the expression "what else [...] they are" (ti allo) in 336a10, Thrasymachus deftly refers to Socrates' open ti allo in giving a closed definition "nothing other than" (ouk allo ti e) in 338c2. This Thrasymachean closed horos is treated as a thesis by his first commentators, Cleitophon $(340 \mathrm{a} 8, \mathrm{~b} 8)$ and Polemarchus (twice in 340b1). Socrates, in turn, will treat the discussion on it in Book 1 as an introduction (prooimion) to further dialogue (357a2).

${ }^{52}$ On the "fondness of ancient audiences for comic mockery," see Bromberg 2018, 33. 
Socrates in the name of the justice determined by legitimate authorities (i.e. the stronger, 339a1) - is quickly abandoned in favour of further comic mockery of Thrasymachus' position (who finally agrees to teach poor Socrates for a fee collected for him by all those present; 337d6-338a8, cf. [H3]), Plato indirectly indicates here that the stakes he has in mind in the discussion on TT as being "another and better" are high indeed. This is because, just as Cephalus' and Simonides' justice, this thesis pertains to a certain moral and political reality, whose mechanisms seem immune to elenctic punches.

Yet Socrates would use elenctics - which is, in this respect, ineffective - also with respect to TT, as if for some reason he were unwilling to approach it differently, at least for the time being. What is more, although Thrasymachus was clear in conveying his irritation with Socrates' method $(336 \mathrm{~b} 8-\mathrm{c} 1)$, the latter would use against the rhetorician the same argument concerning human error with which he had led Polemarchus to aporia (compare 334c6-d8: we err in distinguishing good and evil men, with 339c1-e8: men in power err in distinguishing what is advantageous to them). As confirmed by the surviving prooimion ([D2]), the motif of an erring authority was familiar to the historical Thrasymachus. Regardless of Plato's intention in using this theme, when he had his Thrasymachus counter-attack by saying that according to "precise speech" (kata ton akribe logon) no ruler, "insofar as he is a ruler," makes mistakes (340e1-341a1), ${ }^{53}$ as a result Socrates will confirm the efficacy of elenctics in another respect: by cross-examining whether the addition of "the stronger" is truly megale, he will refer the comic "how" to the unclear "what." This is done through a string of questions (339b7-353a3), in the course of which he will demolish the very thing that determined the perfect (pankalos, cf. 338a7) - according to Thrasymachus' criteria - form of his definition and guaranteed its clarity and precision (cf. 336d2-3), i.e. an apposite terseness. He will reveal that the terse form conceals complex, unclear contents which even Thrasymachus himself did not assume. To this end, Plato constructs for Socrates a suitable dialogue situation, with four noteworthy elements:

(1) Plato incites a dispute about the meaning of TT between its direct recipients, Cleitophon and Polemarchus, in front of Thrasymachus himself (340a1-c5). The two men,

\footnotetext{
${ }^{53}$ The assumption that Plato concentrates on the content of the views ascribed by him to Thrasymachus, and not on the rhetorician's style, is accepted at the outset by many recent commentators on the dialogue (on a diverse set of theories attributed to Thrasymachus, see Anderson 2016, 151). Thus, considering only the contents, this "precise" position of Plato's Thrasymachus is today - as a result of Plato's deliberate mockery or without his conscious design - almost unequivocally accepted as "deeply problematic" (after Nawar 2018, 363; ibid., pp. 370-1 n. 32, the outline of the debate and Nawar's proposal of interpretation; Nawar demonstrates the coherence of Thrasymachus' position, placing it within the "infallibilist strand of ancient thought" concerning techne, and considers it not impossible that this view was shared also by the historical Thrasymachus).
} 
seeing it as not only a definition (horos) that closes shut the reality in a single description, but as a thesis concealing implicit positions, ${ }^{54}$ have no less trouble agreeing on what Thrasymachus said (elegeto, 340b9) than do contemporary interpreters. ${ }^{55}$ Thus, Polemarchus in his exegesis refers to what Thrasymachus set down (etheto) and to what he agreed (340b1-4); Cleitophon refers to what, in his view, Thrasymachus "did say" (elegen, 340b7) and set down (etitheto, b8).

(2) If this is the first dispute over the meaning of TT in its history, yet even Thrasymachus himself, present at the scene, offers no clarification. The meaning inferred by his direct audience - including Cleitophon, presented in the Cleitophon as his disciple! - was not his original message (340c6-7), as it does not always correspond to what he agreed to in his conversation with Socrates - or rather, under Socrates' influence. ${ }^{56}$

(3) By emphasising "precise speech" (akribes logos, 340e2; cf. 342b7, d6, 9) in his approach, and working towards "the most precise way" (to akribestaton, 340e8, 341a8), Thrasymachus progressively distances himself from Socrates' endeavours to present the content assumed in TT as his own views: he does not want to reveal his true beliefs to Socrates (349a9-10); his thoughts are irrelevant, and one needs to consult the argumentation itself (as Socrates advises in 350e11). Thus, the general picture presented in this dramatic framework is that Thrasymachus firmly and consistently defines himself as a proponent of the formal

\footnotetext{
${ }^{54}$ See n. 51 above.

${ }^{55}$ The lack of scholarly consensus regarding the character, intention and coherence of TT results, to a large extent, from the manner of its presentation by Plato (grouped problems with relevant literature in Betti 2011, 34 n. 4-8; outline of scholarly positions in, e.g., Mitchell 2003, 7-8; seven examples of typical interpretive variants in Chappell 1993, 2; analysis of four different interpretations in Cross and Woozley 1964, 23-60; interpretive suggestions in Nawar 2018, 361-2 n. 3). The complexity and multiplicity of aspects evident in Plato's presentation, reflected by the wealth of interpretive variants, contrasts with the initial apt, terse definition that may encompass several discourses, views or observations of different authors who connected in any way whatsoever justice with the benefit of the stronger/the authority (cf. [H2] as an example of including a few persons to one characterisation: Thrasymachus and Theodorus are dressed in one coat; see also Maguire 1971, 144, with references to Xenophon's Memorabilia I 2. 41-46 and pseudo-Xenophon's Athenaion Constitution).
}

${ }^{56}$ See 339b7-e8: the process in which Socrates elicits answers from Thrasymachus, ascertaining his affirmation (homologia) to specific statements, in order to demonstrate that the general TT is in itself contradictory. 340c8-9: Thrasymachus' problematic homologia. 342c10, d2-3, e5: Socrates coerces Thrasymachus to voice his homologia, though not without contestation (machesthai, $\mathrm{d} 3$ ) on the part of Thrasymachus who, as Aristotle recounts, was famed for his fierce (thrasy) fighting spirit (mache; [E]). 346c12: Thrasymachus 'assented with resistance.' 350c12-d2: Socrates' account does not reflect the reluctance of Thrasymachus' affirmation. 350d9-e7: Thrasymachus answers in a way that would please Socrates, ultimately agreeing with him as one would with an old crone spinning fables. 352b3-4: he does not contest Socrates, who - like a Zeus ex machina - uses the argument of the gods' hatred towards unjust men, so as not to alienate the audience with his other statement regarding the gods ([G2]). 353e7-12: he concurs with Socrates' statement, treating it as nothing more than the conclusion of Socrates' line of thought. 
criterion, akribeia, rather than of any given TT which Plato makes him utter in order to accentuate the akribeia ([E4]). Yet again, our problems with attributing TT to the historical Thrasymachus correspond to the problems with attributing TT to Plato's Thrasymachus, arising within the narrative of the dialogue itself. ${ }^{57}$ The content of TT appears not only unclear, but unclaimed as well.

(4) The contrast between the declared assets of Thrasymachus' style (precision and clarity) and the unclear meaning of TT is easily apparent in the scene of its paradoxical revealing in 343a1-2: "it was evident (kataphanes en) to everyone that the argument about just had turned around in the opposite direction" (i.e. in relation to the initial TT). Thus, TT collapses onto the ground of the clarity and precision that it had allegedly possessed.

Confronting the four above-presented situations with the rhetorician's claims to having presented another and better answer to the question of justice (see 337d1-2), one discovers that his claim to betterness seems laughable if measured in terms of clarity and precision. Thrasymachus' further endeavours do nothing to change this impression, as he schools Socrates - whose wet nurse neglects his snivelling nose (343a3-9) and who foolishly believes in the existence of good shepherds who care about the well-being of the sheep weaker than themselves - on how the matter ought to be considered (skopeisthai, 343d1; 344a2). Moreover, in his longwinded - and hence unfolding the taut TT - demonstration of a mature way of thinking about the relations between the weak and the strong (343b1-344c8), Thrasymachus becomes so entangled between the colloquial and the "strict" (akribes) understanding of justice that, by using the terse and ambiguous utterance "injustice is the opposite" (he de adikia tounantion), he ultimately calls the advantage for oneself injustice that rules the just (343c4-7), a weak man - a just man (343c7, d7, e2-4), and a strong man - an unjust man (343d2, e7, 344a3-6, c2-4). Thus, the famed rhetorician - the author of Aphormai retorikai (Rhetorical Starting Points; [B1]), the orator instructing Athenians on how to avert a political crisis by looking at contentious issues "from the beginning" (see [D4] ad skeptestai ex arches) - is treated as follows. At the starting point Plato puts in his mouth a directly stated definition of justice as "the advantage of the stronger," which, when elaborated upon, turns out to be the very definition

\footnotetext{
${ }^{57}$ Blondell 2004, 180-9, offers a different opinion: in portraying Thrasymachus, Plato demonstrates that his thesis corresponds to his authoritarian personality and his method of teaching, i.e. suggests that he is convinced of its accuracy. Cf. also Wedgwood 2017, 34-5, for a more radical interpretation: Thrasymachus gives the coherent and 'official account of justice;' p. 59: his figure foreshadows the tyrannical soul discussed in Books 8 and 9.
} 
of injustice in its ordinary everyday sense: ${ }^{58}$ since "injustice [...] is mightier [...] than justice" (344c5-6) - since practice proves that the unjust can take advantage both of the justice of others and of their own injustice $(343 \mathrm{~d} 3-344 \mathrm{c} 2)$ - then on the one hand (men), "the just is the advantage of the stronger" (as the justice of others/weaker men brings advantage to the unjust), and on the other (de), "the unjust is what is profitable and advantageous for oneself" (as taking advantage of the justice of others/weaker men is unjust) (344c7-8). The fact that Plato's Thrasymachus emphasises - and by using the phrase ex arches, he recalls, as it seems in this context, the language of the historical Thrasymachus (also in 341a3) - that this was his point "from the beginning" (ex arches, 344c6-7), turns the initial TT into a logical fallacy rather than aphorme retorike. However, by entangling the colloquial understanding of justice with its "strict" meaning, the conclusion presented is not as much a logical error of equivocation, but an expression of tangled moral norms and factual human behaviours and tendencies, universal in its ambiguity. This entanglement blends the normative with the descriptive, while justice and injustice switch places depending on the perspective. The resulting exegetic confusion is acknowledged in the dialogue, as Plato's Socrates asks Thrasymachus not to mix words and lead his audience astray (me exapatein, 345b8-9). ${ }^{59}$

\section{TT as an Aphorme Philosophos}

If, therefore, Thrasymachus answered Socrates' call to speak differently of justice (i.e. differently than Polemarchus following an inherited tradition, cf. 336a10) by demonstrating, in his typical style, that justice ought to be regarded "in this way" (houtosi, 343d2), then his "this" is a flawed designation with only a semblance of clarity. He neither taught his listeners adequately nor found out "whether it is so or not" $(344 \mathrm{~d} 7-\mathrm{e} 1)$. Without these elements, his demonstration is but a flood over the listeners' ears (344d2). Precisely because of this semblance of clarity, the need to specify how one should speak of justice remains as unsatisfied as it was in the case of the Simonidean-Cephalean definition. The imprecise, ambiguous content requires a form different from the mercenary, brief admonition delivered by Thrasymachus.

\footnotetext{
${ }^{58}$ Cf. Howland 1993, 70-1; Maguire 1971, 149-51.

${ }^{59} \mathrm{Cf}$. Wedgwood 2017, 37-9, who seems to be omitting this request as he argues that Thrasymachus' conception of injustice at $343 \mathrm{c}-344 \mathrm{c}$ is consistent with his strict definition of justice. However, I agree with him that both conceptions are consistent at 348c-e (see ibidem pp. 40-1).
} 
The necessity to consider the matter in other ways is reflected in the scene where he intends to leave, convinced that he had exhausted the subject, yet is stopped by the others and forced (anankazein) to offer some explanation for his words (paraschein ton eiremenon logon, 344d4), and when Socrates discerns in the concise TT not a trivial problem: it pertains to "a course of life on the basis of which each of us would have the most profitable existence" (344e1-3). Thus, ridiculed in its function of an aphorme retorike, the TT becomes a serious aphorme philosophos for Plato. In other words, it loses its previous function of an agonistic vehicle, becoming a universal and paramount philosophical challenge. ${ }^{60}$ The factors stimulating its transformation into a philosophical tool are all critical in nature. To rephrase, philosophical thought develops because (1) Thrasymachus could not stand the "balderdash" (phluaria) of Socrates' discussion with Polemarchus (336b8), (2) Socrates then failed to applaud Thrasymachus' counterproposal, i.e. the allegedly well-spoken (pankale) thesis (338c3), as he was not able to understand Thrasymachus' meaning (338c4, d6), (3) whereupon Thrasymachus was compelled to demonstrate the veracity of his claim (344d4-5), (4) and eventually Socrates critically evaluated the method he was thereto using to debate with Thrasymachus, taking onto himself all the blame for the confusion (354b1). This critical inspiration with each of the cognitive stages reflects the multi-stage method of Platonic philosophy presented in the Seventh Letter (342a-344b): each individual item by which some being is cognisable (its name, definition, image, and knowledge/reason/true opinion) is unclear in isolation (343b6-7).

But it is the methodical study of all these stages, passing in turn from one to another, up and down, which with difficulty implants knowledge [...] $(343 \mathrm{e} 1-2)^{61}$

There is, therefore, reason to believe that the problems discussed in the contemporary interpretation of TT: whether it is descriptive or normative, ${ }^{62}$ what Thrasymachus actually advocates, whether his argument is cohesive and whether Socrates' counterargument is logically correct ${ }^{63}$ - are not, in fact, issues which motivated Plato's line of thought. By putting

\footnotetext{
${ }^{60}$ For a similar point, but in relation to the entire conversation between Socrates and Thrasymachus, see Putterman 2000, 80: both characters are Plato's creations, allowing him to conduct an argument with himself and involve us; Sørensen 2016, 14: TT is Plato's 'provocative claim;' Wedgwood 2017, 52-3: Thrasymachus plays 'a role for Plato that is akin to the roles played for Hobbes by the bellum omnium contra omnes ... and for Kant by the 'radical evil'.'

${ }^{61}$ Trans. R.G. Bury. See also 344b1-c1. The method is also employed in the Laws (compare Leg. 895d, 898e2 with Ep. VII. 342c4-5; for a commentary, see Mayhew 2011, 126-8).

${ }^{62}$ Cf. Barker 1947, 72; Guthrie 1971, 96; Mitchell 2003, 4-5; Putterman 2000, 82, 89; Chappelll 1993, 3-17; White 1995, 321-2; Anderson 2016, 156-7, 165.

${ }^{63}$ See n. 55 above.
} 
TT in a rich narrative context, he made it into a carefully constructed instrument for awakening cognitive dissatisfaction with every formulated thesis, be it descriptive or normative. In both cases it constitutes merely one of many component stages of philosophical investigation, not the culmination thereof. For this reason, in the form presented by Thrasymachus, TT needs to be unclear and ambiguous, and Plato strove to present it as such. Even when the thesis is expanded and seemingly clarified in the long description in $343 \mathrm{~b} 1-\mathrm{d} 1$, it is treated only as a certain suggestion (not yet evaluated in its effectiveness) for the answer to the paramount need of "each of us" to have "the most profitable existence" (344e2-3). Socrates' agreement with Thrasymachus' claim that justice is however related to advantage (cf. 339a6-8), now directed at the desire for one's own benefit felt by everyone, not only by the stronger, is therefore reiterated. Thus, even though Thrasymachus telescoped in his thesis a bitter description of "the social practice called dikaiosyne, justice," ${ }^{64}$ according to which the stronger preys on the justice of the weaker, Socrates supplements this account of the factual situation with one more aspect, one of far greater importance: the desire of each of us to live a life that is advantageous to oneself. It is not argued in the dialogue, but presented as a primordial fact which needs not be discussed, and which Thrasymachus should also take into consideration if he wishes to teach others (cf. 338a3), explaining how his thesis tackles this universal egotistic desire (344e1-345a1).

The need to include it in the description of the moral and political reality makes TT appear to be an incomplete account; only one of the many possible existential options. In other words, the perspective delineated by Thrasymachus, when he claims that "in this way" (houtosi) we must consider (343d1-2; cf. [D3-4]), is too narrow to lead to a complete understanding of that reality. Even if TT results from a certain political reality, there remains the urgent question of what results from TT for one's own desire to live an advantageous/good life. It is the Platonic question ${ }^{65}$ placed in the dialogue several times: phrased both by Socrates $(344 \mathrm{e} 6,352 \mathrm{~d} 6$, 354c2-3, 545a7, 578c7) and Plato's brothers (365b1), it motivates the further development, concluded in the Myth of Er, by the description of choosing a new life among the many different existential options $(617 \mathrm{e}, 618 \mathrm{c})$.

\footnotetext{
${ }^{64}$ Chappell 1993, 11; see also Anderson 2016, 157-8.

${ }^{65}$ Actually, this is Prodicus' question posed in the speech The Choice of Heracles, as Anderson 2016, 158-161, 163-4, 166, observes. However, Anderson ascribes the topic 'how one should lead one's life' (344e) to Thrasymachus, overlooking Socrates' complaint at 344a6-e7 that Thrasymachus is not aware of the weight (or existential dimension) of the problem he has addressed.
} 


\section{Conclusion}

There is the long road of Platonic philosophy between the moment TT emerges as a single untested existential solution $(344 \mathrm{~d}-\mathrm{e})$ and the final scenes of the dialogue describing the act of choosing one of the multitude of possible lives (618a). This long conversation on the interrelation between the polis and the human soul is an instrument to teach one how to look at the political and moral reality. By opening the possibility of regarding matters from a new perspective $(493 \mathrm{c} 4,497 \mathrm{e} 6,545 \mathrm{a} 6,564 \mathrm{c} 6-7)$ and revealing that mathematical sciences, dialectics and political experience are necessary to broaden one's field of vision and sharpen the sight, it provides more existential solutions than the single choice condensed in TT $(545 \mathrm{a}-\mathrm{b}$ : TT is only one possible option). However, at that first stage of the dialogue, dubbed the prooimion to further conversation (357a2), the potential Plato saw in the unique character of the rhetorician Thrasymachus appears exhausted. Plato had already demonstrated his skill at ethopoiia: his Thrasymachus is not able to explain whether the solution presented in TT guarantees a happy existence, even coaxed by Socrates with the promise of financial gain substantial, as many people would like to hear him answer (345a1-2). Thrasymachus concludes the discussion in his typical manner, briefly and decisively: he said what he had to say, and since he had not managed to convince Socrates, he can do nothing more short of giving his "soul a forced feeding" (345b4-6). Socrates' protest "By Zeus, don't you do it" (345b7) signifies the philosopher's objection to have his living mind chained by a thesis, a definition or a seemingly exhaustive description of reality, lauded as "another and better."

The interest in the colourful character of the Chalcedonian that Plato had thus far awakened in his readers is gradually shifted onto TT, which increases in depth, despite Socrates' seemingly effective attempts at refuting it (345b9-354a9). It may, however, be argued that the effectiveness of Socrates' elenctic method is equally illusory as the quality of being "another and better" so valued by Thrasymachus, given that Socrates not only failed to persuade Thrasymachus and Plato's brothers (357a5-b2, 367b1-e5, 368b6-7), but also that he gained little from the conversation himself, apart from the conclusion that he knows nothing (354b9-c1). This steady change of focus, from the character Thrasymachus to the existential solution summarised in TT (and difficult to refute in a convincing manner), is apparent in the three subsequent parts of the dialogue:

(1) Since the moment Socrates takes note of Thrasymachus' personal views on truth, hidden beneath mockery (349a4-8), Thrasymachus progressively distances himself from the opinions he is presenting. He offers the following caustic retort: "And what difference does it 
make to you, $[\ldots]$ whether it seems so to me or not, and why don't you refute the argument?" (349a9-10). ${ }^{66}$ Could this be a wink of camaraderie directed at the readers to warn them not to associate the views of Plato's Thrasymachus with the eponymous historical figure? Indubitably, the revealing of Thrasymachus allegedly true beliefs promptly followed by the weakening of their connection with the utterer creates the impression that what the rhetorician represents is not his personal view on morality, but - as attested by testimonies - something of a rhetorical display or rivalry ([D1-2], [E4]). Although Thrasymachus blushes at the end of his dispute with Socrates (350d3), he ultimately maintains his inscrutable sage-like face (cf. [F]).

Thus, the dialogue contains no indication that Plato recounts the views of the historical Thrasymachus; it does, however, suggest that he preserves the style of combative rhetoric. The claim to betterness (in this case related to the conciseness and brevity of thought), characteristic of that style, was effectively made to appear laughable by TT. However, this effectiveness only reveals a fraction of its potential. At that stage in the dialogue, the power of the content of TT remains mysterious; as mysterious are the true views of Thrasymachus, both as a historical figure and, as it turns out, as presented by Plato. The readers' attention to the power of TT is directed by Plato - once again subversively - through the act of undermining its claim to "otherness," i.e. by revealing its factual and long-apparent grounding in reality.

(2) The illusory nature of TT's freshness is revealed by Plato's brothers. In Book 2 they take over the role of advocatus diaboli for Thrasymachus who, in their opinion, was too quick to back down under Socrates' arguments (357a3, 358b2-3, 362e4), presenting the cultural arguments of TT. ${ }^{67}$ They are very familiar with the topic: Glaucon even states that he has been "talked deaf by Thrasymachus and countless others" speaking as he does (358c7-8). And so, TT is no longer only Thrasymachus' thesis; it cannot even be called a more or less accurate description of a certain reality - it becomes an expression of schizophrenic cultural norms, instilled in children and respected by the entire community. Ingrained in the earliest poems by Homer and Hesiod, fundamental for religious practices presupposing the possibility of appeasing the gods and collecting one's reward (or punishment) after death - beliefs voiced at the beginning of the dialogue by the legacy-making Cephalus - present in the popular view that

\footnotetext{
${ }^{66}$ Similarly in 351c6-7: Thrasymachus responds as he does only to please (charizomai) Socrates, who approves of such an attitude; 351d7 - so as not to quarrel with Socrates.

${ }^{67}$ Blondell 2004, 181 n. 55 (referring to Grote 1888: IV7), 191 n. 86, compares the role Thrasymachus plays in Book 1 to the function of Thersites in the Illiad - the latter, humiliated and disregarded, voices inconvenient opinions, which are nevertheless worth considering, and are received differently once they come from a more likable character (in the Illiad it is Achilles). On the positive role of Plato's brothers in the later parts of the dialogue see: ibidem, pp. 199-228.
} 
the just (as opposed to the unjust) lead a harsh life full of suffering, and, as emphasised by Adeimantus, in many cultural and customary norms (367a5) - such norms are expressed in the opinion that although justice is a virtue to be strived for, one should nevertheless do it for the promise of some advantage (362e1-367a8). This is but a step away from the belief that it sometimes makes sense for justice to be subordinate to personal gain (especially if no one is watching); and if one has the potential for securing one's advantage - i.e. holds power and authority - it is easy to equate the voice of the stronger/authority with the voice of law and justice. Thus, TT's claim of "otherness" could not receive harsher ridicule. It becomes apparent that it is an old tune heard everywhere, in countless reiterations.

Again, however, the originality could lie not in the thought itself, but in the concise form - which, not elaborated upon, appears to be a slogan. However, as this illusory "otherness" of TT's content is revealed, i.e. its factual and perpetual role in reality becomes known, the TT itself is transformed into a serious philosophical challenge, regardless of who presents it and what means they use. This universality and de-condensation makes it worthy of the term logos $(358 \mathrm{c} 1,359 \mathrm{~b} 5,360 \mathrm{~d} 2,362 \mathrm{~d} 3)$.

(3) If TT is an expression of a certain mentality shaped by specific social, moral and cultural norms, the answer to the question as to whether other norms are possible and how they could be implemented substantiates TT's evaluation in terms of adequacy in describing human reality: TT is a description of reality grounded in a certain normative and cultural convention, with an open question as to the possibility of accepting other norms. ${ }^{68}$ Thus, the line between the descriptive and normative nature of TT becomes blurred. It is also apparent that TT cannot be refuted using the elenctic method, but may only be juxtaposed with other paideutic and moral norms, along with the political culture formed thereon, yet with an awareness of the susceptibility to norms that form the base of the TT; susceptibility conditioned by the complexity of the human soul and its inherent desire. ${ }^{69}$

\footnotetext{
${ }^{68}$ The positive exposing role of the slogan that is TT with regard to traditional morality was emphasised by Barney 2017, yet with the reservation that 'it is somewhat misleading to treat the Republic as a whole as a response to Thrasymachus'. Cf. also Burnyeat 2013, 212-3, 226, where it is argued that Plato's concept of justice is not directed at Thrasymachus.

${ }^{69}$ See: the description of the mechanisms behind the degeneration of any political system and its associated psychological system, even the best one - in 546a-568d; the mythical illustration of the world's inborn desire (sumphutos epithumia, Plt. 272e6), instilled in living beings and initiating the cycle of political life - in Statesman (269d-e; 271e-273b). Hitz 2013, 106-109 emphasises the fact that the power of desire implied in TT appears in the description of the degenerated systems in Books 6 and 8 as 'both ubiquitous and undesirable - and without the rule of reason, inevitable.'
} 
In Books 2 to 10 Plato formulates and tests an alternative model of culture, based on other theological and moral values (tupoi) than those accepted by most and perpetuating TT's viability as a definition (379a5-380c3), ${ }^{70}$ and thereby he suggests that the matters of men can be regarded in yet another way. In doing so, Plato shatters yet another illusion: the illusion of TT's determinism. If, unlike the prisoners in the cave, doomed to believe that the norms they see implemented are the only just ones, or, as Plato puts it, unable to "turn their heads" away from the shadows on the wall $(514 \mathrm{~b} 1-2)$, we exercise our minds, the broader perspective will reveal that TT is only one of the possible options for a more or less advantageous/good life, which a thinking individual moving their head may choose. ${ }^{71}$ The form of shutting one of these options in the tight fetters of "nothing else than" (338c2), so characteristic for Thrasymachus' rhetoric, is not conducive to thinking outside the box. Halfway through the dialogue, Plato makes his Thrasymachus acknowledge this limitation, as he voices his wish to listen to a different, long conversation about politeia $(450 \mathrm{a}-\mathrm{b})$, because, as Plato's brother will put it, "for intelligent men [...] the proper measure of listening to such argument is a whole life" $(450 \mathrm{~b} 6-7)$.

\footnotetext{
${ }^{70}$ Cf. 364b2-365b1, where Adeimantus, arguing for Thrasymachus, reveals the factual theological and moral norms TT is based on.
}

${ }^{71}$ I agree with Putterman $(2000,83)$ that 'Thrasymachus is intent on showing us ... the way things really are. Plato may not agree, but it is important that he introduces us to Thrasymachus in order to make us aware that he is aware of the most serious of all objections to his Republic: that it is just another Cloudcuckooland.' However, Plato may have been deliberate in creating the impression that the Callipolis described in the further sections of the dialogue is 'another Cloudcuckooland,' in order to force the reader to shift the perspective they look from at the content of TT perpetuated in culture. Regardless of the accuracy of its terse description of the status quo, the TT is an expression of culturally sanctioned norms which may be confronted with other normative conventions. How can this be done? That is what Plato demonstrates in creating a Callipolis 'in speech' (logo, 369a6) easily and provocatively - as if carried by the wind of $\log 0$ s (394d8-9), with no certainty of being right $(450 \mathrm{e}-451 \mathrm{a})$ - thus, giving trouble to his interpreters from Proclos to contemporary scholars (see Hitz 2013, 104-5). Freed from the constraints of habit and supposed naturalism (456c2: the known familiar relations are but a convention), the Callipolis proves that the alleged realism of TT is relative: by unmasking it as nothing more but an implemented conventional option, and juxtaposing it with another solution - no matter if it is implemented or not $(472 \mathrm{~d}-\mathrm{e})$, what matters is whether that option is 'psychologically possible' (to use Stephan Menn's term: after Hitz 2013,106 n 18) - the Callipolis blurs the antithesis between Thrasymachus' 'realism' and Socrates' 'Cloudcuckooland,' although in traditional interpretation the two are often juxtaposed, with the latter being called 'the ideal city' (see Wardy 2013, 132, for a similar point: 'much of his [Plato's] politics is realist rather than idealist, a fact too often ignored.') Thus, Plato presents us with a choice, impossible within the framework of TT. The ability to develop the right criterion for this choice requires a long, multi-stage philosophical journey, on which Plato invites his audience to embark in the Republic. The first step thereon is 'moving one's head,' i.e. accepting the possibility that matters may be regarded from a different perspective, as a change in optics affects moral sensitivity (cf. Farrar 2013, 36-53). 
Dorota Zygmuntowicz

Polish Academy of Sciences, Institute of Philosophy and Sociology,

Department of Ancient and Mediaeval Philosophy

\section{Acknowledgment}

I am grateful to the Institute of Philosophy and Sociology of Polish Academy of Sciences for a research grant in 2018, which gave me support of my work on this article.

\section{Bibliography}

Anderson, Merrick, 2011. "Thrasymachus' Sophistic Account of Justice in Republic I." Ancient Philosophy 36: 151-172. https://doi.org/10.5840/ancientphil201636110

Athenaeus. The Deipnosophists. Trans. C.D.Yonge. London: Henry G. Bohn. 1854.

Barker, Ernest, 1947. The Political Thought of Plato and Aristotle. $3^{\text {rd }}$ ed. New York: Barnes \& Noble, Inc.

Barney, Rachel, 2017. "Callicles and Thrasymachus." The Stanford Encyclopedia of Philosophy (Fall 2017 Edition), Edward N. Zalta (ed.), https://plato.stanford.edu/archives/fall2017/entries/calliclesthrasymachus/

Benardete, Seth, 1989. Socrates'Second Sailing. On Plato's Republic. Chicago: University of Chicago Press.

Betti, Daniel, 2011. "The Search for the Political Thought of the Historical Thrasymachus." Polis 28(1): 33-44. https://doi.org/10.1163/20512996-90000177

Blondell, Ruby, 2004. The Play of Character in Plato's Dialogues. Cambridge: Cambridge University Press. https://doi.org/10.1017/CBO9780511482472

Bloom, Alan, 1968. The Republic of Plato. New York: Oxford University Press.

Blundell, Mary Whitlock, 1989. Helping Friends and Harming Enemies. A Study in Sophocles and Greek Ethics. Cambridge: Cambridge University Press. https://doi.org/10.1353/phl.1990.0055

Boardman, John/ Griffin, Jasper/ Murray, Oswyn, 1986 (eds.). Oxford History of Classical World. Oxford: Oxford University Press.

Bromberg, Jacques A., 2018. "A Sage on the Stage: Socrates and Athenian Old Comedy." In Alessandro Stavru/ Christopher Moore (eds.), Socrates and Socratic Dialogue. Leiden: Koninklijke Brill, 31-63. https://doi.org/10.1163/9789004341227_003

Burnyeat, M.F., 2013. "Justice writ large and small in Republic 4." In Verity Harte/ Melissa Lane (eds.), Politeia in Greek and Roman Philosophy. Cambridge: Cambridge University Press, 212-230. https://doi.org/10.1017/CB09781139096843.015

Chappell, T.D.J., 1993. “The Virtues of Thrasymachus' Phronesis 38: 1-17. https:// doi.org/10.1163/1568528 93321052424

Cross, R.C. \& Woozley, A.D., 1964. Plato's Republic: A Philosophical Commentary. London \& Toronto: Macmillan Co 
Diels, Hermann/ Kranz, Walther, 1956. Die Fragmente der Vorsokratiker. Vol. II, $8^{\text {th }}$ ed. Berlin: Weidmannsche Verlagsbuchhandlung.

Dobson, John Frederick, 1919. The Greek Orators. New York: Methuen.

Dornseiff, Franz, 1941. "Platons Politeia Buch I." Hermes 76: 111-112.

Farrar, Cynthia, 2013. "Putting history in its place: Plato, Thucydides, and the Athenian politeia." In Verity Harte/ Melissa Lane (eds.), Politeia in Greek and Roman Philosophy. Cambridge: Cambridge University Press, 32-56. https://doi.org/10.1017/CB09781139096843.003

Ferrari, G.R.F., 2013. "Socrates in the Republic." In Mark L. McPherran (ed.), Plato's Republic. A Critical Guide. Cambridge University Press, 11-31. https://doi.org/10.1017/CB0970511763 090.002

Friedländer, Paul, 1957. Platon. Bd. II: Die platonischen Schriften. Erste Periode. Berlin: Walter de Gruyter \& Co.

Friedländer, Paul, 1960. Platon. Bd. III: Die platonischen Schriften. Zweite und dritte Periode. Berlin: Walter de Gruyter \& Co.

Grote, George, 1888. A History of Greece. London: J. Murray.

Guthrie, W.K.C., 1971. The Sophists. Cambridge: Cambridge University Press.

Harrison, E.L., 1967. "Plato's Manipulation of Thrasymachus." Phoenix 21(1): 27-39.

Havelock, Eric Alfred, 1957. The Liberal Temper in Greek Politics, New Haven: Yale University Press.

Hitz, Zena, 2013. "Degenerate regimes in Plato's Republic." In Mark L. McPherran (ed.), Plato's Republic. A Critical Guide. Cambridge Cambridge University Press, 103-131. https:// doi.org/10.1017/CB09780511763090.007

Hourani, George F., 1962. “Thrasymachus' Definition of Justice in Plato's Republic.” Phronesis 7: 110-120. https://doi.org/10.1163/156852862X00070

Howland, Jacob, 2004. The Republic: The Odyssey of Philosophy. Philadelphia: Paul Dry Books.

Kerferd, G.B., 1947. "The Doctrine of Thrasymachus in Plato's Republic." Durham University Journal 9: 19-27. https://doi.org/10.1163/156852864X00032

Kerferd, G.B., 1964. “Thrasymachus and Justice: A Reply.” Phronesis 9: 12-16.

Kutash, Emilie, 2007. "What did Plato read?" Plato 7: 1-20 (https://digitalis-dsp.uc.pt/bitstream/ 10316.2/42217/3/What_did_Plato_read.pdf).

Laks, André/ Most, Glenn W., 2016. Early Greek Philosophy. Vol. VIII Sophists, Part I. Cambridge, MA: Harvard University Press.

Ledger, G.R., 1989. Re-counting Plato. Oxford: Clarendon Press.

Livingstone, Niall, 1998. "The Voice of Isocrates and the Dissemination of Cultural Power." In Y.L. Too/ N. Livingstone (eds.), Pedagogy and Power: Rhetorics of Classical Learning. Cambridge: Cambridge Iniversity Press, 263-281. https://doi.org/10.1017/CB09780511552731.013

Lycos, Kimon, 1987. Plato on Justice and Power. Reading Book I of Plato's Republic.

London: Macmillan.

Maguire, J.P., 1971. “Thrasymachus ... or Plato?” Phronesis 16: 142-163. https://

doi.org/10.1163/156852871X00098

Mayhew, Robert, 2011. Plato. Laws 10. Oxford: Clarendon Press.

Mitchell, B./ Lucas, J.R., 2003. An Engagement with Plato's Republic. Aldershot: Ashgate.

Munn, Mark, 2000. The School of History: Athens in the Age of Socrates. Berkeley: University of California Press. 
Nails, Debra, 2002. The People of Plato: A Prosopography of Plato and Other Socratis. Indianapolis: Hackettt.

Nawar, Tamer, 2018. "Thrasymachus' Unerring Skill and the Arguments of Republic 1." Phronesis 63: 359-391. https://doi.org/10.1163/15685284-12341354

Nederman, Cary J., 2007. "Giving Thrasymachus his Due: The Political Argument of Republic I and its Reception.” Polis 24: 26-42. https://doi.org/10.1163/20512996-90000106

Pausanias, Description of Greece. Vol. III: Books 6-8.21. Trans. W.H.S. Jones. Loeb Classical Library 272.

Putterman, Theodore L., 2000. "Socrates/Thrasymachus: The Extent of their Agreement." Polis 17(1 -2): 79-90. https://doi.org/10.5840/philinquiry1997193/46

Reeve, C.D.C., 1988. Philosopher-Kings: The Argument of Plato's Republic. Princeton NY: Princeton University Press.

Schofield, Malcolm, 2006. Plato. Political Philosophy, Oxford: Oxford University Press.

Schöpsadu, Klaus, 1994. Platon: Werke. Übersetzung und Kommentar, IX 2 Nomoi (Gesetze), Buch I-III. Göttingen: Vandenhoeck \& Ruprecht.

Sparshott, F., 1966. "Socrates and Thrasymachus." Monist 50 (3): 421-459. https:// doi.org/10.5840/monist196650330

Storey, I.C., 1988. "Thrasymachus at Athens: Aristophanes fr. 205 ("Daitales").” Phoenix 42: 212218.

Sørensen, Anders Dahl, 2016. Plato on Democracy and Political techne, Leiden/Boston: Brill. https:// doi.org/10.1163/9789004326194

Taylor, A. E., 1966. Plato, the Man and his Work. London: Methuen (repr.).

Thesleff, Holger, 1967. Studies in the Style of Plato (repr. in H. Thesleff 2009, 1-142).

Thesleff, Holger, 1982). Studies in Platonic Chronology (repr. in H. Thesleff 2009, 143-382).

Thesleff, Holger, 2009. Platonic Patterns. A Collection of Studies by Holger Thesleff.

Parmenides Publishing.

Wardy, Robert, 2013. "The Platonic manufacture of ideology, or how to assemble awkward truth and wholesome falsehood." In Vanity Harte/ Melissa Lane (eds.), Politeia in Greek and Roman Philosophy. Cambridge University Press,119-138. https://doi.org/10.1017/CB09781139096843.007

Wedgwood, Ralph, 2017. "The Coherence of Thrasymachus." Oxford Studies in Ancient Philosophy 53: 33-63. https://doi.org/10.1093/oso/9780198815655.003.0002

White, StephenA., 1995. "Thrasymachus the Diplomat." Classical Philology 90: 307-327. https://doi.org/10.1086/367477

Yunis, H., 1997. “Thrasymachus B1: Discord, not Diplomacy.” Classical Philology 92: 58-66. https://doi.org/10.1086/449331 